\title{
WestVirginiaUniversity
}

THE RESEARCH REPOSITORY @ WVU

Graduate Theses, Dissertations, and Problem Reports

2012

\section{Etude Books for Horn Published from 1985 to 2011: An Annotated Guide}

Joseph David Johnson

West Virginia University

Follow this and additional works at: https://researchrepository.wvu.edu/etd

\section{Recommended Citation}

Johnson, Joseph David, "Etude Books for Horn Published from 1985 to 2011: An Annotated Guide" (2012). Graduate Theses, Dissertations, and Problem Reports. 3588.

https://researchrepository.wvu.edu/etd/3588

This Dissertation is protected by copyright and/or related rights. It has been brought to you by the The Research Repository @ WVU with permission from the rights-holder(s). You are free to use this Dissertation in any way that is permitted by the copyright and related rights legislation that applies to your use. For other uses you must obtain permission from the rights-holder(s) directly, unless additional rights are indicated by a Creative Commons license in the record and/ or on the work itself. This Dissertation has been accepted for inclusion in WVU Graduate Theses, Dissertations, and Problem Reports collection by an authorized administrator of The Research Repository @ WVU.

For more information, please contact researchrepository@mail.wvu.edu. 
Etude Books for Horn Published from 1985 to 2011:

An Annotated Guide

\section{Joseph David Johnson}

Research project submitted to the

College of Creative Arts at West Virginia University

in partial fulfillment of the requirements for the degree of

Doctor of Musical Arts

in

Performance

D.M.A. Committee

Dr. Mitchell Arnold

Dr. Ernest Goeres

Dr. Keith Jackson

Dr. Andrew Kohn

Dr. Virginia Thompson, Chair and Research Advisor

School of Music

Morgantown, West Virginia

2012

Keywords: Horn, Etudes

Copyright 2012 Joseph D. Johnson 


\section{ABSTRACT \\ Etude Books for Horn Published from 1985 to 2011: An Annotated Guide}

\section{Joseph David Johnson}

The purpose of this project is to provide an annotated guide of etude books for the horn that were newly written or published between 1985 and 2011. This document lists sixty-eight different etude books written for the horn, and provides annotations for fifty-six of these publications. The annotations include the following information: publisher, publication date, range, transposition, number of etudes, and difficulty rating. In addition, the annotations describe performance problems that may be encountered, such as extended techniques and issues concerning technical facility or flexibility. Since the goal of this document is to promote the use and acceptance of new horn literature, recommendations for further study are included in the summary.

The majority of current university professors tend to use etude books that are known as standards of the repertoire and have stood the test of time. This list normally includes the volumes of books written by Maxime-Alphonse, who died in 1930, and Georg Kopprasch, who died in 1832. Even popular etude books that are considered newer and are widely used, such as John Shoemaker's Legato Etudes for French Horn, for which the copyright was renewed in 1971, are actually older and were written well before 1985. There are dissertations that catalogue and offer annotations for all of the horn etude books written and published before 1985, but none that deal with more recent literature. This document continues the work begun by previous dissertations, and provides students and teachers with a resource that will introduce them to new and important etude literature. 


\section{Acknowledgements}

I would like to thank my committee members, Dr. Mitchell Arnold, Dr. Ernest Goeres, Dr. Keith Jackson, and Dr. Andrew Kohn for their valuable input and support concerning this document. I would especially like to thank my teacher, Dr. Virginia Thompson, without whom this project would not have been possible.

Last but not least, I would also like to thank my wife, Hannah, for her love and continual support in my academic endeavors. 


\section{Table of Contents}

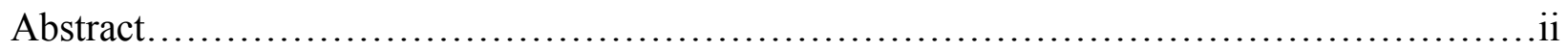

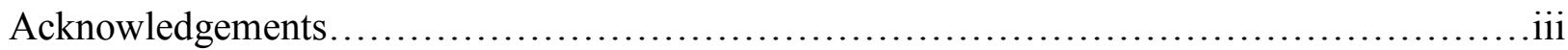

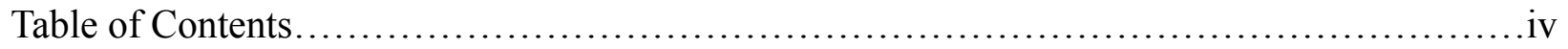

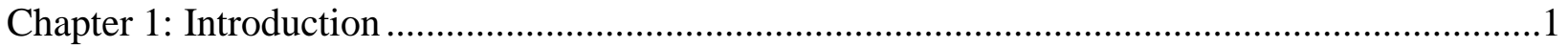

Statement of the Topic .......................................................................................

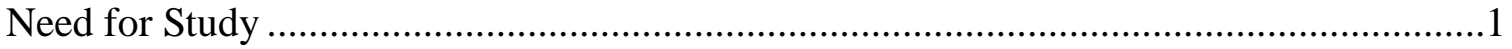

Limitations on the Scope of the Research............................................................

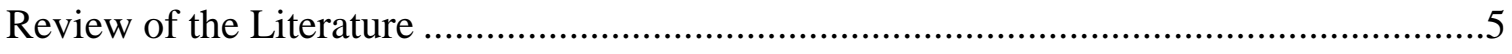

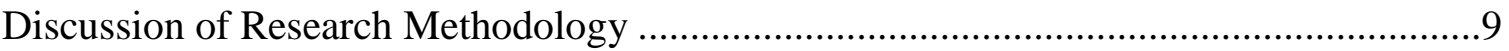

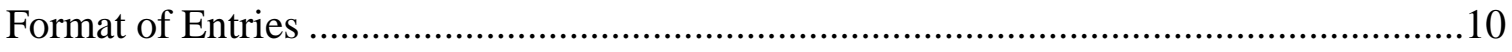

Chapter 2: Annotations for Etude Books Written or Published from 1985 to 2011 ....................13

Chapter 3: Bibliographical Listing of Etude Books without Annotations .................................65

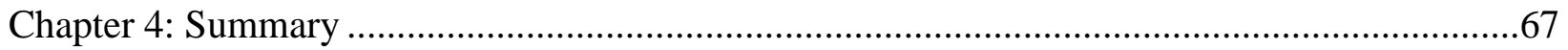

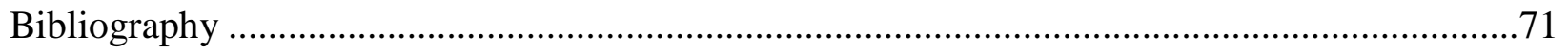

Appendix A: Bibliographical Listing of Composers and Works .........................................75

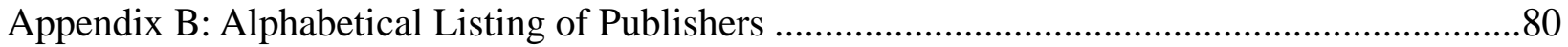

Appendix C: Chronological Listing of Compositions by Publication Date ..............................81

Appendix D: Contemporary Etude Books Listed Alphabetically by Composer .......................84 


\section{Chapter 1: Introduction}

\section{Statement of the Topic}

The purpose of this project is to provide an annotated guide of etude books for the horn from 1985 to 2011. The annotations give performance related details concerning difficulty and range, as well as a brief description discussing the specific aspects of horn playing that are addressed in each etude book. These descriptions refer to whether or not a book focuses on a specific range, developing flexibility, increasing technical proficiency, hand horn playing, or other areas of interest. This document was written to aid hornists in sifting through the multitude of etude books that have been published during the last thirty-six years. More importantly, it also serves as a reference source for pedagogues and allows teachers to find books that meet the specific needs of students.

\section{Need for Study}

The majority of etude books in use today are standards of the repertoire that were published before 1985. Numerous bibliographies exist that catalog other types of horn music and there are three dissertations written by Marvin Howe, Herbert Koerselman, and Johnny Pherigo that contain annotated bibliographies of etude literature written before 1985, but none deal extensively with the etude books written and published within the last thirty-six years. Douglas Hill's book, Collected Thoughts on Teaching and Learning, Creativity, and Horn Performance, contains a listing of popular and important etude books with annotations, but it gives an 
annotation for only one book written after $1985 .^{1}$ Another similar source is Verne Reynolds's The Horn Handbook, which contains a section offering in-depth discussions pertaining to selected etude books. Unfortunately, this section does not discuss any books written after $1983 .^{2}$

Many pedagogues and university teachers provide lists of appropriate etude books for students. The majority of these lists include one or two recent additions to the etude repertoire, but many teachers prefer the more traditional books that have been in use since the mid-twentieth century, such as those by Georg Kopprasch, Verne Reynolds, and Maxime-Alphonse. ${ }^{3}$ Even John Shoemaker's Legato Etudes for French Horn and Martin Hackleman's 34 Characteristic Etudes for Low Horn Playing, which are very popular among hornists and considered to be newer additions to the literature, are older books published in 1971 and 1978. With this in mind, it seems that there is a definite need for a bibliography listing the available etude books written during the last thirty-six years.

At the writing of this document, the main source for discovering new etude books is The Horn Call, the scholarly publication of the International Horn Society. This journal has been publishing reviews of new music since 1971 and often reviews new contributions to the etude repertoire. The one drawback is that not every horn player is a member of the IHS and even members sometimes have difficulty pinpointing the edition containing the desired review. Many of these reviews may be accessed through online search databases via EbscoHost, but again not

1 Douglas Hill, Collected Thoughts on Teaching and Learning, Creativity, and Horn Performance (Miami, FL: Warner Bros., 2001), 152-157.

2 Verne Reynolds, The Horn Handbook (Portland, OR: Amadeus Press, 1997), 51-96.

3 Maxime-Alphonse is a pseudonym used by the French horn player, Jean Marie Maximin François Alphonse (birth name is Griet). 
every student, performer, or even pedagogue has access to the full-text reviews from The Horn Call. Also, the full-text articles are only available for reviews published in The Horn Call since May 2006. We need an extensive bibliography of recent etude books for horn, so that these important contributions to the literature may be appreciated and studied.

\section{Limitations on the Scope of the Research}

Since there are a multitude of etude books that have been issued within the last thirty-six years, method and drill books are excluded from this document. The terms method book and drill book refer to the literature that specifically deals with warm-up routines or contains short, concise exercises that address physical development in patterns that focus on technical goals at the expense of artistic expression. These terms also refer to studies consisting of specific patterns or rhythmic figures that are repeated at different pitch levels for the sole purpose of expanding range or flexibility, such as David Ware's Low Horn Flexibility Studies. This does not mean that they are less important, but only that the addition of these texts would significantly broaden the scope of this research project and require the assessment of too much literature. Etude books have been specifically chosen for this project because of their value in teaching and preparing students for advanced solo, chamber, and orchestral playing.

This document does include etude books that were written for varieties of instruments if an edition was specifically written for the horn, or if horn appears in the title. For example, Bill Holcombe's 12 Intermediate Jazz Etudes for French Horn and Fred Lipsius's Reading Key Jazz Rhythms are both available for a number of different instruments, but there is an edition of each 
specifically written for the horn.

The etude books included in this document consist mostly of newly composed works written between 1985 and 2011; however, there are many works that have been rediscovered and newly published within the last thirty-six years. This includes Kopprasch's high horn etudes published in 2000 and the set of twelve etudes by J.R. Lewy that have been edited and published by three separate editors since 2002. Several works that have been revised or newly transcribed for horn are also included in this bibliography, such as Vincenz Ranieri's Thirty Instructive and Melodic Exercises for French Horn and Mathilde Marchesi's 24 Volkalisen für Horn. Finally, this document also includes dissertations written after 1985 that contain newly composed etudes. These works offer original material that is significant due to the scholarly importance of each dissertation. My research has uncovered sixty-eight etude books, which are all included in this study. Any books or documents that were not received by March 30, 2012 still appear in this document in chapter 3; however, these works are not accompanied by a detailed description of their contents.

The year 1985 is a suitable date, because much etude literature has been written or rediscovered and published during the last thirty-six years, and not enough time has passed to allow many of these undiscovered gems to find a home in the standard repertoire. The primary reason to start at 1985 is because three dissertations that catalog the available etude literature prior to 1985 already exist. There are numerous important etude books written before 1985, but the majority of these books are well-known and considered standards of the repertoire. This 
document will serve to expose hornists to the multitude of valuable etude books written within the last thirty-six years and continue the work of Howe, Koerselman, and Pherigo.

\section{Review of the Literature}

As stated previously, there are a few older dissertations that contain annotated bibliographies of etude literature, but none that deal extensively with more recent literature. The first to discuss is Marvin Howe's 1966 dissertation, "A Critical Survey of Literature, Material, Opinions, and Practices Related to Teaching the French Horn.” The bibliographical listing of available etude books in 1966 is extensive, while the annotations are short, normally a paragraph in length. The annotations do give specific range requirements and discuss important aspects, but most descriptions are very general in nature. ${ }^{4}$

The next dissertation to include an annotated guide to horn etude literature is Herbert Koerselman's 1976 work, “An Annotated Bibliography of Brass Study Materials which Deal with Performance Problems Encountered in Contemporary Music.” Since this work deals with all brass instruments, the bibliographical listing of horn etude books is not as extensive as Howe's, but Koerselman does include some newer works published after the completion of Howe's dissertation. The annotations are also more in-depth, and include descriptions pertaining to the tonal and rhythmic characteristics of each set of etudes. ${ }^{5}$

Johnny Pherigo's 1986 dissertation, “A Critical Survey of Materials and Practices Related

4 Marvin C. Howe, "A Critical Survey of Literature, Material, Opinions, and Practices Related to Teaching the French Horn.” (Ph.D. diss., University of Iowa, 1966), 348-365.

5 Herbert LeRoy Koerselman, "An Annotated Bibliography of Brass Study Materials which Deal with Performance Problems Encountered in Contemporary Music" (D.M.A. diss., University of Iowa, 1976), 89-111. 
to Teaching the Horn, 1965-1985," is a continuation of Howe's work. The bibliography is extensive and the annotations are similar to the previously discussed annotations found in Howe's and Koerselman's documents. ${ }^{6}$ Other more recent dissertations discussing etude literature exist, but the main goal of these documents is not to compile an extensive list of the available horn etude literature. These dissertations, such as Travis Bennett's “A Horn Player's Guide: Using Etudes, Solos, and Orchestral Excerpts to Address Specific Technical and Musical Challenges" finished in 2003 and Jessica Thoman's "Method and Etude Books and the Orchestra: How Method and Etude Books for Horn Reflect the Changing Orchestral Repertoire" completed in 2006, use etudes to aid in discussing the evolution of repertoire, or teaching specific techniques on the horn. Bennett includes one non-traditional etude book in his discussion and does not include annotations in his work. ${ }^{7}$

Thoman's work includes both method and etude books, but does not contain an extensive listing of contemporary works. She discusses only one recent book, Douglas Hill's Extended Techniques for the Horn: A Practical Handbook for Composers and Performers, which was published in $1983 .{ }^{8}$ It is important to note that a second edition of this work with a compact disc of recorded examples was published by Warner Bros. Publications in 1996 and reprinted in 2000. ${ }^{9}$ Thoman focuses primarily on tracing the evolution of orchestral repertoire for the horn

6 Johnny Lee Pherigo, "A Critical Survey of Materials and Practices Related to Teaching the Horn, 1965-1985" (D.M.A. diss., University of Illinois at Urbana-Champaign, 1986), 121-140.

7 Travis Andrew Bennett, "A Horn Player's Guide: Using Etudes, Solos, and Orchestral Excerpts to Address Specific Technical and Musical Challenges" (D.M.A. diss., The University of Alabama, 2003), 138-140.

8 Jessica Thoman, "Method and Etude Books and the Orchestra: How Method and Etude Books for Horn Reflect the Changing Orchestral Repertoire" (D.M.A. diss., Indiana University, 2006), 12.

9 Douglas Hill, Extended Techniques for the Horn: A Practical Handbook for Students, Composers, and 
and the effect this literature had on the method and etude books written since the eighteenthcentury. She is very selective and includes only twelve books in her discussion.

Aside from the dissertations that discuss the body of published etude literature, there are several documents that offer new additions to the literature. These include the following dissertations:

Dean, David. "Improving Left-Hand Finger Dexterity: Etudes for French Horn.” D.M.A. diss., University of Northern Colorado, 1993.

Deats, Carol. "Toward a pedagogy of extended techniques for horn derived from Vincent Persichetti's 'Parable for Solo Horn,' Opus 120.” D.M.A. diss., Texas Tech University, 2001.

Hansen, Jeremy Christian. "A Creative Pedagogical Approach to Hindemith's Music for Horn and Piano with Thirty Progressive Etudes.” D.M.A. thesis, University of Iowa, 2009.

Hopper, Kathleen Kenyon. "A Performance Edition of Thirty Instructive and Melodic Exercises for French Horn by Vincenz Ranieri." D.M.A. diss., University of North CarolinaGreensboro, 2007.

Miller, Brett Edward. "45 Concert Studies on the Themes of Richard Strauss, Gustav Mahler and Johannes Brahms.” D.M.A. diss., University of Maryland, 2007.

Thompson, Timothy F. "Extended Techniques for the Horn: An Historical Overview with Practical Performance Applications.” D.M.A. diss., University of Wisconsin-Madison, 1997.

Hansen's work offers thirty original etudes inspired by the music and techniques of

Hindemith. Hopper's document supplies horn players with a new and improved edition of Ranieri's classic etude book. Miller offers forty-five new etudes based on themes by Strauss, Mahler, and Brahms in his dissertation, while Deats takes inspiration from Persichetti's Parable

Performers, Second Edition (Miami, FL: Warner Bros., 1996). 
for Solo Horn in her document. Dean and Thompson take a different route from the previously discussed dissertations by composing completely original works designed to address specific technical demands on the horn.

There are also two articles written by Douglas Hill and Kristin Thelander that are often cited in dissertations discussing etude literature. Thelander's article, "Selected Etudes and Exercises for Specialized Practice," published in the May 1994 edition of The Horn Call, is a great source for those seeking etude books to address specific needs, such as endurance, accuracy, and legato playing. Thelander gives several etude recommendations for each category and also provides a short annotation for each etude book. Unfortunately, she discusses only two contemporary etude books, while the rest were published before $1985 .{ }^{10}$ Douglas Hill's article, "Selected Published Materials for the Development and Utilization of a Contemporary Horn Technique," published in the May 1978 edition of The Horn Call, is a listing of etudes, unaccompanied solos, and solos with piano that promote the advancement of technique. Each section is categorized by difficulty, beginning, intermediate, advanced, and virtuosic, and no publication dates are given. Also, the annotations are very short, typically a sentence briefly describing the types of exercises or technical aspects addressed in each work. ${ }^{11}$

10 Kristin Thelander, "Selected Etudes and Exercises for Specialized Practice," The Horn Call 24, no. 3 (May 1994): $54-56$

11 Douglas Hill, "Selected Published Materials for the Development and Utilization of a Contemporary Horn Technique," The Horn Call 8, no. 2 (May 1978): 50-52. 


\section{Discussion of Research Methodology}

Numerous sources, both online and in print, were consulted while compiling the list of etude literature for this project. Internet search engines, primarily google.com and yahoo.com, yielded links to websites maintained by university professors. These websites often contained lists of important etude literature, but the majority of lists rarely included more contemporary works. Searches through the following music catalogues supplied better results: Hickey's Music Center (hickeys.com), Pope Instrument Repair (poperepair.com), Hans Pizka's Horn Page (pizka.de), Thompson Edition (thompsonedition.com), and Robert King Music (rkingmusic.com).

The aforementioned catalogues provided many unfamiliar works to peruse, while searches in "WorldCat" via EbscoHost supplied publication dates for a majority of the literature. The most helpful source by far was the "Music Review" section of The Horn Call. This journal is currently published three times a year, and a majority of the issues contained at least one review of a newly written or published etude book. ${ }^{12}$ This was an invaluable source, considering the fact that there is no extensive bibliography or book that catalogues etude literature written or published within the last thirty-six years.

Also, searches in "RILM" and "ProQuest" through EbscoHost aided in discovering relevant dissertations to this topic. This included abstracts for all of the dissertations used for this project, except for Jessica Thoman's work. "ProQuest" also provided full-text pdf files of

12 The Horn Call was published twice a year from 1985 to 1993, three times a year from 1994 to 1997, four times a year from 1998 to 2001, and three times a year since 2002. 
dissertations by the following authors: Bennett, Hansen, Hopper, Howe, Koerselman, Miller, Pherigo, and Thompson.

\section{Format of Entries}

The annotated entries in this bibliography range from a half page to a full page in length. The length depends on the amount of material in each book and the need to discuss important concepts or difficult horn techniques present within each publication. Entries are organized as follows:

\section{Composer}

Title

Composition/Publication Date

Publisher

Range

Transposition

Number of Etudes

Difficulty

Description of Contents

Range is indicated using the octave designation system preferred by The Horn Call, which is shown in Figure $1 .^{13}$ This system of designation is also used in The New Harvard Dictionary of Music, edited by Don Randel. Within the "Description of Contents" sections, all pitches are indicated as they are written in the music.

13 "Guidelines for Content Contributors," http://www.hornsociety.org/en/publications/horn-call/contributorguidelines (accessed on December 17, 2011). 
Figure 1: Octave Designation System from the website of the International Horn Society

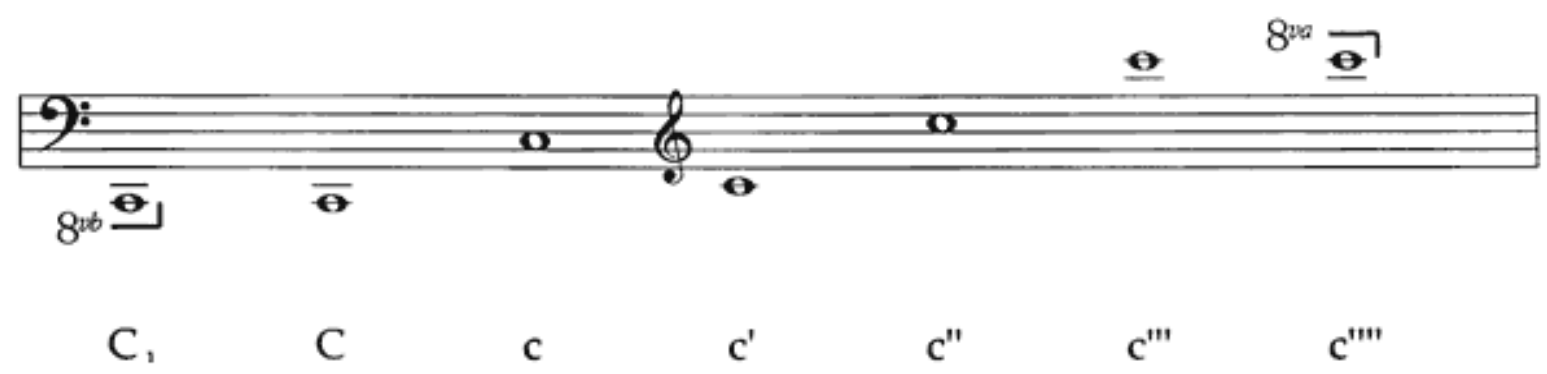

Level of difficulty is designated using Roman numeral classification ranging from I-VI.

Each rating is based on the following classification system, which is adapted from the

performance standards found on the website of the National Association for Music Education: ${ }^{14}$

I - Easy/Beginner: Very easy. Easy keys, meters, and rhythms; limited ranges.

II - Intermediate: Junior High level. Easy. May include changes of tempo, key, and meter; modest ranges.

III - Moderate: Advanced Junior High/Early High School. Moderately easy. Contains moderate technical demands, expanded ranges, and varied interpretive requirements. IV - Moderately Difficult: Advanced High School or Early-Mid Collegiate level. Requires well-developed technical skills, attention to phrasing and interpretation, and ability to perform various meters and rhythms in a variety of keys.

V - Advanced: Difficult. Requires advanced technical and interpretive skills; contains key signatures with numerous sharps or flats, unusual meters, complex rhythms, subtle dynamic requirements.

VI - Extremely Difficult/Virtuosic: Graduate Student or Professional Player. Suitable for musically mature students of exceptional competence.

The descriptions for each entry briefly discuss the etudes in each book. These range from discussing the technical demands to how beneficial certain studies may be for developing endurance or proficiency in a particular register of the horn. If studies are written in bass clef, it

14 "Performance Standards for Music: Notes," http://www.menc.org/resources/view/performance-standards-formusic-notes (accessed on December 19, 2011). 
is mentioned whether or not they are in old or new notation. When using old notation, bass clef notes are written an octave lower than intended, whereas new notation is notated in the correct octave and sounds a fifth lower than written. Special attention is also given to those etudes that are derived from preexisting melodies or based on certain major orchestral themes. This is important to note, because these etudes are beneficial study aids for those preparing the corresponding orchestral or solo works. 


\section{Chapter 2: Annotations}

Composer: Atwell, Bruce

Title: Natural Horn/Valve Horn Technical Etudes: Strengthening Valve Horn Playing through Natural Horn Study

Composition/Publication Date: 2001

Publisher: RM Williams

Range: G - d"'

Transposition: F, E, E-flat, D, G, A

Number of Etudes: 30

Difficulty: VI

Description of Contents:

The preface to this book discusses the differences and similarities of the natural and valve horns. This preface also covers right hand technique and talks about the benefits of practicing natural horn playing on a regular basis. Each page is essentially one etude, and Atwell gives specific instructions for performance at the top of each page. This book is divided into two sections. Within the first section, the etudes on the left facing page are natural horn studies, while the etudes on the right facing pages are valve horn studies. The natural horn etudes are limited to notes within the harmonic series, while the valve horn studies are chromatic throughout. The studies begin with easy whole, half, and quarter note passages, but quickly progress to eighth note patterns that tend to stay mostly in the upper register of the horn. Page eighteen requires the performance of lip trills in the upper register, above a written $\mathrm{g}^{\prime \prime}$ at the top of the staff.

In the second section, each etude is to be performed without valves first, and then played through again with valves. These studies will require a firm understanding of the hand-stopping technique when played through on the hand horn. All of the etudes in the second section are still tonal, but contain many chromatic passages. Atwell also begins to write shorter passages in this 
section. Essentially, each page contains several one or two line passages that accentuate a particular valve combination or difficult hand shift. At page thirty, Atwell lengthens the studies and begins to base them on important works, such as the Mozart horn concerti or important orchestral works.

These studies do not offer many artistic challenges, but do contain a wide variety of technical challenges for both the valve and hand horns. Some of the earlier exercises would be suitable for younger students, but starting with page ten, the etudes begin to require a great deal of playing in the extreme upper register of the horn. The extreme range, plus the dexterity and knowledge required to perform some of the hand horn passages are the primary reasons for the high difficulty rating.

Composer: Barrows, John R.

Title: Development Exercises and Etudes for Horn

Composition/Publication Date: $2008^{15}$

Publisher: Wind Music

Range: f\# - c'"

Transposition: None

Number of Etudes: 10

Difficulty: IV-V

Description of Contents:

The exercises in this book are written to address a specific area of horn technique, which includes flexibility across the registers, endurance, finger dexterity, breath control, legato playing, high register building through the use of glissandi, and both lip and valve trills. Only exercises $3,4,5,6,8$, and 10 are actually etudes, while the other exercises are drill material. The etudes are tonal and focus on either lyrical or technical aspects. This work is reprinted in its

15 This is a reproduction of the original material written by John Barrows, who died in 1974. 
original, hand-written form, so some of the studies are difficult to read. Each exercise is also accompanied by instructions and helpful hints written by Barrows.

Composer: Basler, Paul

Title: Etudes for Horn, Vol. 1 \& 2

Composition/Publication Date: 1998

Publisher: RM Williams

Range: E - c"'

Transposition: None

Number of Etudes: 48

Difficulty: V-VI

Description of Contents:

These etudes are dedicated to William Purvis, and are similar in style and level of difficulty to the etude books written by Gunther Schuller, Verne Reynolds, and Georg Kopprasch. All of the studies in this work are technically and lyrically challenging, and focus on the following aspects: high horn, low horn, scalar patterns, mixed meter, stopped horn, arpeggios that cross registers, accuracy, and syncopated rhythms. These works are rhythmically complex, and Basler frequently employs the use of uncommon meters, such as 5/8 and 7/8. Many of the etudes also contain mixed meter and often shift between duple and compound meter. Almost all of the studies are accompanied by a suggested tempo marking, which is often very brisk and challenging. Most cover nearly the entire range of the horn and require the player to maneuver quickly between the registers. A number of these studies contain a great deal of playing in the upper register of the horn above a written g". Basler also frequently shifts between writing in treble clef and bass clef, with the latter appearing in new notation. 
Most of these works also contain ornaments and extended techniques, which include turns, lip trills, valve trills, flutter tongue, and stopped horn. There are many difficult stopped horn passages throughout the work, including an etude that is played entirely using stopped horn. Basler also writes an etude that is to be played specifically using the harmonic series of the natural horn. For this etude, he includes the valve or combination of valves to use to simulate the changing of crooks.

Composer: Braun, Yehezkel

Title: Twelve Preludes for Unaccompanied Horn

Composition/Publication Date: 1985

Publisher: Israel Brass Woodwind Publications

Range: c - c"'

Transposition: None

Number of Etudes: 12

Difficulty: V-VI

Description of Contents:

These works are suitable for both instructional and soloistic purposes. Braun's preludes are very challenging and contain complex rhythms and challenging technical passages. In the preface, he encourages students to look beyond the technical demands and focus on expression and other artistic challenges present in each prelude. All of the works are written in different styles that are contrasting in tempo and utilize different metrical combinations. The preludes are written in both simple and compound meters, and many of the studies frequently shift between meters. For example, Etude VI shifts between 5/8, 6/8, and 7/8, Etude XI constantly alternates between $5 / 8$ and $3 / 8$, and Etude XII shifts between $5 / 8,6 / 8,7 / 8$, and 8/8. The etudes also contain 
many wide, non-diatonic intervallic leaps that will test a player's ear and flexibility. Braun does not include key signatures, but the preludes do contain definite tonal centers.

Composer: Brown, Richard E.

Title: 18 Contemporary Etudes for Horn

Composition/Publication Date: 2006

Publisher: RM Williams

Range: $f$ - g"

Transposition: None

Number of Etudes: 18

Difficulty: IV

Description of Contents:

These studies range from three-fourths of a page to two pages in length. There are no key signatures, but the etudes do contain tonal centers and frequently modulate. The etudes gradually progress in difficulty, adding more demanding rhythms, time signatures, and intervallic leaps in later etudes. Most of the studies are written in simple, duple meter, but there are several that include mixed and compound meter. For example, Etude Nos. 5 and 18 are written in mixed, compound and simple meters, and contain the following time signatures: $2 / 4,3 / 4,3 / 8,5 / 8,6 / 8$, and 7/8. There is a nice mixture between slow, fast, lyrical, and technical studies, and Brown progressively includes more specific articulation, dynamic, and other artistic markings throughout the book. These etudes are never overly demanding in terms of range or technical facility.

Composer: Colson, John F. and David J. Colson Title: Rhythm \& Pulse: Reading Music for the Trumpet and French Horn Player (or for any treble clef instrument player)

Composition/Publication Date: 2001

Publisher: McCoy's Horn Library

Range: c - g\#" 
Transposition: None

Number of Etudes: 21

Difficulty: IV-V

Description of Contents:

The first seven chapters of this book are almost entirely comprised of drill material, and focus on the following areas: reading simple and complex rhythms, recognition of musical patterns, articulation, range, accuracy, flexibility, key signatures, chromatic scalar patterns, accidentals, transposition, and reading in bass clef. There are three short etudes at the end of the chapter on articulation, and two etudes at the end of chapter 7 that are written in bass clef. These short exercises are moderate in range and comprised of basic rhythmic elements. Chapter 8 contains sixteen etudes that are meant to review and reinforce the issues addressed in the drill material from the previous chapters. The range for these etudes tends to stay between written $\mathrm{g}$ and g", due to the fact that these studies are intended for both trumpet and horn players.

Rhythmically, many of the later etudes are challenging and present complex rhythms, including tuplet rhythms ranging from triplets to septuplets and eighth, sixteenth, and thirty-second note rhythms that will require steady sub-division. There is an etude written in 5/8 and 7/8, and Etude No. 10, which is written in 12/8, contains many duple figures that are either two against three or four against three. Most of the etudes are tonal, and all are accompanied by suggested tempo markings and include phrase markings as well.

Composer: Concone, Giuseppe; edited by Robert Ashworth Title: Concone Studies for Horn

Composition/Publication Date: 1997

Publisher: Emerson

Range: F - a-flat" 
Transposition: Suggested transpositions include: B-flat alto, A alto, A-flat alto, G, E, E-flat, D, D-flat, C, B basso, B-flat basso, A basso, A-flat basso, and transposing down a full octave Number of Etudes: 26

Difficulty: V-VI

Description of Contents:

The etudes in this book are very accessible and well-written. These works do not require much high horn playing and there is nothing too out of the ordinary in terms of rhythm. The etudes in $3 / 8$ and 12/8 may be tricky for younger, inexperienced players, but most of these works should not present too many rhythmic issues. As mentioned, these etudes are very well-written and are full of artistic and stylistic challenges that should prove beneficial for those players needing to develop a wider range of expression. Although this work seems suitable for younger students, it receives a high difficulty rating due to the presence of bass clef writing using old and new notation, as well as the transposition recommendations suggested by the editor, Robert Ashworth, the current principal horn of the Orchestra of Opera North in Leeds, England. To give an example of the transposition requirements, Ashworth recommends that Etude 21 also be played in the keys of G, E, E-flat, D, C, B-flat basso, and down one octave.

This version of the Concone studies stands out from the rest due to the inclusion of transposition by Ashworth. Many of the etudes in this work are also quite different from the Concone studies edited by John Sawyer and published in 1972. There are some exact duplications, but a majority of the studies either contain new material or have been altered to better suit the horn's range. There is also a piano accompaniment book available separately.

Composer: Concone, Giuseppe, Mathilde Marchesi, and Heinrich Panofka; compiled and edited by Larry Clark 
Title: Studies in Lyricism for Horn in F

Composition/Publication Date: 2007

Publisher: Carl Fischer

Range: g - b-flat"

Transposition: None

Number of Etudes: 45

Difficulty: II-V

Description of Contents:

All of the forty-five etudes in this book are taken from the vocalises and studies written by Concone, Marchesi, and Panofka, who were all well-known vocal pedagogues during the nineteenth century. The earlier studies present basic rhythms and are not demanding in range. All of the etudes generally stay in the middle register of the horn, although later studies occasionally stretch the range beyond the written $\mathrm{g}$ " at the top of the staff. Each etude presents artistic challenges, especially regarding dynamics, phrasing, and general interpretation. As the book progresses, the rhythms introduced become progressively more difficult, and the keys and time signatures used for each etude become more complex. The etudes range from a half a page to two pages in length, and Clark provides a tempo marking for each etude. Clark also includes breath marks in each etude.

The first several Concone etudes also appear in Sawyer's edition of the Concone studies with a few minor differences. Clark changes certain notes, articulations, dynamics, and rhythms. The later Concone etudes in Clark's edition offer different material from the studies found in the editions by Ashworth, Sawyer, and Wagner.

Composer: Concone, Giuseppe; edited by Corbin Wagner Title: 32 Lyrical Studies for Horn

Composition/Publication Date: 2011 
Publisher: Cornopub

Range: c - b-flat"

Transposition: None

Number of Etudes: 32

Difficulty: IV-V

Description of Contents:

These studies are meant to aid the student or professional player in developing phrasing skills, which include being able to recognize proper phrase lengths, portraying the correct style of the music, using enough air support to produce a specific color, and developing the personal skill level to play each phrase with finesse. Wagner includes a numbered listing of helpful hints for each etude that he calls the "Musician Assistant." The numbered tips refer to specific problems or performance related issues found in an etude, and Wagner places the number of the hint at the corresponding point in the music.

All of the etudes in this book correspond to those in John Sawyer's edition of the Concone studies for trumpet or horn. Wagner's edition is unique, because he transposes many of the etudes into different keys. For instance, Etude 13 is written in C major in Sawyer's edition, while it appears in D-flat major in this edition. This allows Wagner to explore more difficult key areas, and include low register playing that extends the range below a written g. He also includes the use of bass clef writing in old notation in Etude 12.

Composer: Davies, Alison

Title: Four Studies

Composition/Publication Date: 1994

Publisher: Broadbent \& Dunn

Range: c - f\#"

Transposition: None

Number of Etudes: 4 


\section{Difficulty: III-IV \\ Description of Contents:}

These four studies are tonal and not very difficult in terms of rhythm. Each etude is written with a specific concept or style in mind. Study No. 1 uses the four notes A, B-flat, C\#, and F, spread throughout the different octaves, while No. 3 uses five notes, E-flat, F, G, A, and C. Study No. 2 is written in a waltz style with a swing feel, while No. 4 is characterized by the rhythmic pulse of its $5 / 8$ meter. Some younger students may be challenged by the use of $4 / 8$ and $5 / 8$ time signatures in the last etude, but the rhythms are notated in a way that simplifies counting and should allow the student to easily feel the rhythmic pulse. All of the studies contain contrasting dynamics, and Davies also includes a few stopped written f's in No. 3. These studies are meant to be performed as a suite for solo horn, but could be used as etude material.

Composer: Dean, David Todd

Title: "Improving Left Hand Finger Dexterity: Etudes for French Horn"

Composition/Publication Date: 1993

Publisher: University of Northern Colorado ${ }^{16}$

Range: F - b-flat"

Transposition: None

Number of Etudes: 6

Difficulty: V

Description of Contents:

Dean's etudes appear in the appendix of his ninety-two page dissertation and are derived from original material. He includes a fingering chart and instructs students working through these etudes to use only the specific fingerings designated in the chart. Each etude is written in a particular style, and include the following: processional, march, waltz, dirge, and toccata. All of

16 Dean's dissertation is only available by requesting it through the University of Northern Colorado Library. 
the etudes are tonal, even though Dean designates a key signature for only two of the six etudes: the other etudes include numerous accidentals and frequently modulate.

Each etude is accompanied with a suggested tempo marking. Although the rhythms are not complex, Dean writes many passages that will be technically challenging for many horn players, due to the presence of wide intervallic leaps. He also does not confine his etudes to a specific range. Each study often quickly shifts between the octaves. Bass clef writing is in new notation, and several stopped notes are included.

Composer: Deats, Carol

Title: "Toward a pedagogy of extended techniques for horn derived from Vincent Persichetti's 'Parable for Solo Horn,' Opus 120."17

Composition/Publication Date: 2001

Publisher: Texas Tech University

Range: $G_{1}-e^{\prime \prime}$

Transposition: Yes, but the composer does not give specific keys

Number of Etudes: 30

Difficulty: IV-VI

Description of Contents:

These etudes are part of a larger dissertation, and appear in Appendix B. They are meant to be used as teaching tools for those students working on extended techniques. As the title states, all of the extended techniques and other issues are derived from Vincent Persichetti's Parable for Solo Horn, and include the following: extended upper register above a written c"', extended low register below a written $\mathrm{C}$, stopped horn, echo horn, half-step hand glissandi, articulations, releases, multiple tonguing, flutter tonguing, lip and valve trills, transposition, glissandi, timbral contrast, and vibrato. The etudes are mostly tonal and are never longer than a

17 This dissertation is available as a pdf download through the website of the Texas Tech University Libraries. 
page in length. There are no major concerns in terms of rhythm, but the extended techniques and extended ranges do add an extra level of difficulty. Deats designates the technique or issue that each etude addresses, and includes instructions and helpful hints for each study. She also bases most of the etudes on themes and rhythmic passages from certain important works. These works include the following, and are listed in order of appearance:

Chopin, "Prelude No. 4 in E minor" from Preludes, op. 28

R. Schumann, "Seven Pieces" from Album for the Young, op. 68

Paganini, Caprice 24, op. 1

Brahms, Wiegenlied, op. 49, no. 7

Rossini, William Tell Overture

Rimsky-Korsakov, Scherherazade

Rimsky-Korsakov, Flight of the Bumblebee

A. Corelli, "Sarabande" from Sonata for Violin and Cembalo, op. 5, no. 8

Vivaldi, "Spring" from The Four Seasons

Beethoven, Pastorale Symphony, Movement II

Paganini, 24 Caprices, op. 1

Beethoven, Leonore Overture, No. 3

Purcell, "Dido's Lament" from Dido and Aeneas

Tchaikovsky, Symphony No. 5, Movement II

Composer: Denniss, Graeme Wright

Title: Studies for Low Horn

Composition/Publication Date: 1993

Publisher: D:composition

Range: F - e-flat"

Transposition: None

Number of Etudes: 23

Difficulty: IV

Description of Contents:

These are graded studies that progress in difficulty throughout the book. The range is also gradually extended further into the lower register with each successive etude, withholding the low written F until Etude 14. The studies typically range from a half page to a page in length, and 
are written in varying styles, which range from the common scherzo or waltz style to swing, ragtime, and jig. All of the etudes are tonal and should not be overly challenging in terms of rhythmic difficulty. Denniss writes many of these studies in the style of the second horn parts of Beethoven, Haydn, and other Classical period composers. This means that a number of the etudes in this book contain wide leaps that require students to maneuver quickly between the registers. All of the etudes contain bass clef writing in new notation, and many of the works alternate between bass and treble clef.

Composer: Dijoux, Marc

Title: 50 Études Romantiques pour Cor d'Harmonie, Trompette, ou Clarinette

Composition/Publication Date: 1985

Publisher: Editions Robert Martin

Range: $c$ - a"

Transposition: None

Number of Etudes: 50

Difficulty: IV

Description of Contents:

All of these etudes are written in familiar keys, contain fairly straightforward rhythms, and are short in length. The longest etudes in this book are not quite a full page long, and the range requirements are moderate, due to the fact that these studies are also intended to be performed on the trumpet and clarinet. Dijoux does, however, add stopped horn passages and lower note options specifically for the horn. Most of the etudes are similar in style, and each etude contains clear dynamic, articulation, and phrase markings. Many of the etudes are written in theme and variation form. Typically, one etude contains the theme, while the following two or three etudes are variations on this particular theme. For some of the etudes, Dijoux gives the 
player the option to play the study in common or cut time. He also includes the use of valve trills throughout the book.

Composer: Edwards, Brad

Title: Simply Singing for Winds: A Wellspring of Melodies for Building Tone and Technique (Low Treble Clef: Horn)

Composition/Publication Date: 2009

Publisher: Self-published

Range: $c$ - c'"

Transposition: None, although it is encouraged to transpose these studies into different keys.

Number of Etudes: 152

Difficulty: III-V

Description of Contents:

This book contains over one hundred melodies that are meant to aid students in

developing skills related to tone, phrasing, articulation, and intonation. Edwards also mentions that these melodies may be used to work on buzzing, sight singing, sight reading, and

transposition. The studies are short, with most ranging between two and four lines in length. All

of the etudes are tonal, and many of them are based on folk tunes from several different

countries, including America, England, Ireland, and Scotland. Edwards does alter many of the folk tunes, and also includes original melodies.

Edwards divides his etudes into five different sections, with each section focusing on a certain musical aspect, such as musical style, legato playing, technical facility, and different rhythms and meters. Almost all of the etudes are presented in two different keys, and some of the melodies are arranged as duets. The studies gradually progress in difficulty and range within each section. Many of the etudes stretch the range above a written g", and several of the melodies that appear later in the book are written in odd meters, such as 5/8 and 7/8. Edwards instructs 
players to buzz and sing through each etude before playing it on the horn. He even includes chord symbols for selected studies, and mentions that students should sit at the piano and play through the chord changes while singing or buzzing the melody. It is also possible for two players to create their own duets using the chord symbols. This book is also available for trumpet/clarinet, trombone/euphonium, and tuba.

Composer: Faust, Randall E.

Title: Interval Etudes for Horn

Composition/Publication Date: 2001

Publisher: Faust Music

Range: B - a"

Transposition: None

Number of Etudes: 11

Difficulty: IV

Description of Contents:

The etudes in this book typically range from half a page to a full page in length. Each etude is based on a specific interval, beginning with major and minor seconds, and ending with major sevenths. The final etude includes all of the intervals used in the previous etudes. Most of the etudes stay within the middle register of the horn, except for the final two. These works are rhythmically and technically challenging, especially those that contain tuplet rhythms and wide intervallic leaps. Faust also includes more complex meters, such as 5/8, 7/8, and 10/8. These etudes present many technical challenges, and each one is written in a different character and includes different artistic demands pertaining to phrasing, articulation, and dynamics.

Composer: Faust, Randall

Title: The Hornist's Jokebook: A Book of New Etudes for Horn

Composition/Publication Date: 1994

Publisher: Faust Music 
Range: F - b-flat"

Transposition: None

Number of Etudes: 15

Difficulty: IV-V

Description of Contents:

These etudes are written with the specific purpose to keep horn players from becoming bored with practicing. This collection is called a jokebook, because most of the etudes are scherzi, and scherzo is the Italian word for joke. The scherzo etudes are all fast, and a few are accompanied by the marking "AFAP," which means to play as fast as possible. The etudes generally focus on a specific difficult aspect of horn playing such as slurs, lip trills, or playing fast technical passages. Almost all of the etudes are written in compound meters, with the most common meter being 5/8. Most of the etudes are rhythmically straightforward, but the etudes in $2 / 8,5 / 8$ and, $7 / 8$ may prove challenging, especially when performed at a fast tempo. There are two slower, legato etudes, but the majority of these studies are designed to keep the brain active by requiring the player to constantly subdivide. Most of the etudes contain odd intervallic leaps that will test a player's flexibility and technical facility. Faust includes stopped horn passages, bass clef writing in new notation, and lip slurs. A few of the etudes consist of a series of lip slurs that are to be performed using specific fingerings.

Composer: Freiberg, Gottfried V. Title: Naturhornschule: 160 Übungen für Naturhorn oder Jagdhorn/Natural Horn School: 160 Exercises for Natural Horn or Hunting Horn

Composition/Publication Date: 1985

Publisher: Hans Pizka

Range: c - g"

Transposition: None, although these studies could be transposed into different keys Number of Etudes: 160 


\section{Difficulty: I-IV}

\section{Description of Contents:}

All of the etudes in this book are very brief and limited to the $\mathrm{C}$ (i.e., concert $\mathrm{F}$ ) harmonic series. The earlier studies are not rhythmically difficult, but later exercises do gradually increase in difficulty. For instance, the first twelve etudes are limited to whole notes and half notes, while eighth notes do not appear until Etude 48. Freiberg also gradually expands the range throughout the book. The written $\mathrm{c}$ is withheld until Etude 65, and the written $\mathrm{g}$ " is not introduced until Etude 89. Rhythmically, these studies are very straightforward, but Freiberg does include more technically demanding rhythms in many of the later etudes. Dynamic markings are scarce, but the studies often vary in style. This book is published in manuscript (hand-written), which does make some of the etudes difficult to read, especially when ledger lines are involved.

Composer: Friedman, Stanley

Title: Four Etudes for Trumpet, Horn, or Clarinet

Composition/Publication Date: 1986/1996

Publisher: Éditions Bim

Range: $g$ - c'"

Transposition: None

Number of Etudes: 4

Difficulty: IV-V

Description of Contents:

These etudes are challenging in terms of lyricism and technical facility, and are meant to be used as both solo and study material. Each etude is written for a particular professional trumpet player, and the names of these players are as follows in the order of dedication: JeanPierre Mathez, Scott Moore, Marvin Stamm, and Jerry Boots. The pitch content of these works is primarily organized in a serial fashion, which means that the etudes often contain wide intervallic 
leaps that are non-diatonic. Friedman does, however, intentionally include points of tonal reference in each study. All four etudes are rhythmically challenging due to the fact that the meter often shifts from simple to compound. Friedman also uses complex meters, such as 5/8, 6/16, and 9/16. Etude II, which is in a subdivided 4/4, often includes sixteenth note and thirtysecond note rhythms. Friedman incorporates certain extended techniques, such as lip and finger trills, as well as a tremolo. Since these studies are also meant to be used by trumpet and clarinet students, the range of these etudes does not extend beyond a written $\mathrm{g}$ below the staff.

Composer: Grabois, Daniel

Title: Twenty Difficult Etudes for the Horn's Middle Register

Composition/Publication Date: 2009

Publisher: Daniel Grabois (www.danielgrabois.com)

Range: F - g"

Transposition: None

Number of Etudes: 20

Difficulty: V

Description of Contents:

These works are meant to offer fun yet challenging studies that focus on developing stability and control in the middle register of the horn, more specifically the written range g-g". The etudes in this book do not require a great deal of high register playing, and most never reach a written g". They are rhythmically challenging, and contain numerous technical passages that will challenge a player's ability to accurately and quickly shift between the middle and low register of the horn. These studies also contain artistic challenges related to phrasing, dynamics, and articulation. Grabois writes many of his etudes in mixed meter, and frequently uses 
complicated meters, such as $5 / 8,7 / 8,3 / 16,5 / 16,6 / 16$, and $7 / 16$. He mentions in the preface that the smallest subdivisions always stay constant when the meters fluctuate.

The etudes are all written in varied styles, and most of them are tonal, although there are some that are completely atonal or a mixture of the two. Grabois frequently shifts between the use of treble and bass clef, with the latter being written in new notation. He also includes a number of extended techniques, which include lip trills, tremolos played in the style of lip trills, flutter tongue, and stopped horn. There are some extended passages in certain etudes that focus specifically on lip trills and stopped horn.

Composer: Hackleman, Martin

Title: 21 Characteristic Etudes for High Horn Playing

Composition/Publication Date: 1985/New edition published in 1990

Publisher: Éditions Bim

Range: D - e'"

Transposition: None

Number of Etudes: 21

Difficulty: VI

Description of Contents:

All of the studies in this book are based on the clarinet etudes written by Cyrille Rose, a nineteenth century clarinetist. Hackleman's etudes cover a wide range, stretching from the bass clef register into the extreme upper register of the horn, beyond written c"'. These studies are primarily intended to improve facility and flexibility in the high register, but are also melodically and artistically rewarding to perform. Each etude contains complex rhythms and large intervallic leaps that are often wider than an octave. Hackleman includes suggested tempo markings for each study, even though most of the studies contain rubato and other subtle fluctuations in 
tempo. Many of the etudes also include difficult stopped horn passages and lip trills in the middle and high register of the horn.

Composer: Hansen, Jeremy Christian

Title: "A Creative Pedagogical Approach to Hindemith's Music for Horn and Piano with Thirty Progressive Etudes"18

Composition/Publication Date: 2009

Publisher: University of Iowa

Range: d - b-flat"

Transposition: None

Number of Etudes: 30

Difficulty: III-V

Description of Contents:

These etudes appear as chapter 9 of Hansen's dissertation, and typically range from one to one and a half pages in length, with the longest etudes being two pages. The etudes are not written using functional tonality, but they all do contain clear tonal centers. Hansen also includes some modal, whole tone, and chromatic elements in several of the studies. Each etude is accompanied by a suggested tempo marking, and the meter includes both simple and compound meters: $2 / 2,3 / 2,4 / 2$, and $6 / 4$.

Hansen writes each of the studies with a specific intervallic pattern, key area, or rhythmic aspect in mind. For instance, Etude No. 3 is based on minor thirds and includes some chromaticism, while Etude No. 27 is built around separate rhythmic and melodic motives from Hindemith's music. Chapter 10 of this dissertation includes Hansen's comments concerning the contents of each etude. Rhythmically, the beginning etudes are limited to long held notes and

18 This dissertation is available as a pdf download through ProQuest Dissertations and Theses. 
quarter notes, while later etudes progress in difficulty and present challenging intervallic patterns and technical passages. These studies also contain many odd intervallic leaps.

Composer: Holcombe, Bill

Title: 12 Intermediate Jazz Etudes for French Horn

Composition/Publication Date: 1994

Publisher: Musicians Publications

Range: $f$ - f"

Transposition: None

Number of Etudes: 12

Difficulty: IV

Description of Contents:

This work is part of a series of books that are also available for the following instruments:

flute, clarinet, trumpet, alto sax, tenor sax, and trombone. All of these books are accompanied with a compact disc that contains recordings demonstrating each etude, as well as a separate rhythm section accompaniment for each etude. A section containing performance suggestions written by the author prefaces the etudes, which discusses the jazz rhythms used within the etudes, talks about performing quarter, eighth, sixteenth notes, and triplets in swing style, and gives tips for improvisation. Each etude is derived from an existing popular jazz tune, although these works do not necessarily appear in the same key as the originals. Holcombe's etudes are composed using the following keys in order to be more accessible to younger students: C, A minor, F, D minor, B-flat, E-flat, and G.

The etudes themselves are written in contrasting styles, ranging from rock and bossa nova to swing. The range requirements are very moderate, and the rhythmic and technical demands are never too difficult, even though the last few etudes do contain some tricky syncopated rhythms. 
Holcombe provides jazz chord symbols throughout each etude, which is very beneficial for those students attempting to improvise along with the rhythm section accompaniment. Since these same etudes are also available for other instruments, it is possible to form small jazz combo groups and perform the etudes together along with the compact disc accompaniment.

Composer: Hopper, Kathleen Kenyon, Editor

See the entry for Ranieri, Vincenz on pp. 53-54.

Composer: Hulin, Éric

Title: 15 Études à Notation Classique et Contemporaine/15 Studies with Classical and Contemporary Notation

Composition/Publication Date: 1998

Publisher: Billaudot

Range: $f$ - b'

Transposition: None

Number of Etudes: 15

Difficulty: I-II

Description of Contents:

These studies are intended for beginning horn students. Each etude is brief and stays within the middle register of the horn. The studies are divided into four sections, with each section focusing on a specific technical aspect. The first four etudes focus on detached notes, the next five concentrate on alternating between staccato and legato articulations, Etude 10 adds accidentals, while the last five are intended to aid young players in the performance of extended techniques that may be found in contemporary music. The first ten etudes are very straightforward, but younger students will require some guidance while working through the etudes with contemporary techniques. The techniques that Hulin includes in these studies are as follows: tapping lightly on the bell without playing, using vibrato, trills, rhythmic crescendo and 
decrescendo, holding note for a prescribed amount of time, noodling around on notes either in a specific order or not, playing natural harmonics, singing into the horn, flutter-tongue, blowing into the instrument without playing, playing the highest and lowest possible notes, glissandi, and playing a note and then depressing the valves rapidly while following the written pitch curve.

Composer: Hulin, Éric Title: 20 Études Concertantes sur 5 Notes/20 Studies on 5 Notes in Concertante Style Composition/Publication Date: 1999

Publisher: Billaudot

Range: $c^{\prime}$ - c"

Transposition: None

Number of Etudes: 20

Difficulty: I

Description of Contents:

These studies are very simple and very short in length. Each etude is in the key of C major and there are no accidentals. Note lengths are limited to quarter, half, dotted-half, and whole notes. Hulin also does not include dynamics or articulation markings. The range covered within the whole book is an octave, but each etude is limited to just five notes spanning half an octave.

Composer: Irwin, James S. Title: 85 Melodic and Rhythmic Studies for French Horn

Composition/Publication Date: 1990

Publisher: Self-published

Range: c - f"

Transposition: E-flat, E, and G

Number of Etudes: 85

Difficulty: II-IV

Description of Contents: 
Most of the studies in this book are short, typically two or three lines in length, with the longest etude being slightly less than a page. The etudes are basic in rhythm and range at the beginning, but progress in difficulty as mixed and asymmetrical meters are introduced. All studies are written in a folk-like style, and are modal. Irwin does not include dynamic or other expression markings, but does encourage students in the preface to experiment with adding musical and expressive elements. Several etudes include bass clef writing in new notation, while Etude No. 29 is written in old notation. There are also a few studies that contain multiple transpositions. For instance, Etude No. 36 alternates between F, G, and E-flat, while Etude No. 45 alternates between F, G, E, and E-flat. The transpositions change quickly, but these studies are written using simple quarter and half note rhythms.

Composer: Kling, Henri; edited by Lee Bracegirdle Title: 25 Studies and Preludes for Horn.

Composition/Publication Date: 1881/1985

Publisher: International Music Co.

Range: $C$ - c'"

Transposition: None

Number of Etudes: 25

Difficulty: IV-V

Description of Contents:

This is a new edition of the original work published by Kling in 1881 . These studies are typically a half a page in length, with the longest two etudes being a full page. Each etude is tonal, and is written in either simple or compound meter. Several of the studies are unmetered, and the different musical ideas are separated by breath marks. All of the etudes are technically 
challenging, and contain sixteenth note, thirty-second note, and tuplet passages that will test a player's flexibility.

The studies in this book are intended to be played using the valve horn, but Kling does include sections that utilize hand horn technique. Many of the etudes contain passages that are to be played using certain valve combinations, which serve as crooks. For instance, using the second valve puts the horn in the key of E, the first valve in the key of E-flat, and so forth. The valve combinations are written over the corresponding passages, and Kling also includes a "+" sign over those notes that fall outside of the harmonic series and need to be manipulated using the right hand. Kling provides a guide in the preface that outlines the different notes that can be produced using each valve combination. The studies also include grace notes, turns, and one etude, No. 7, that is a lip trill study.

Composer: Kopprasch, Georg; edited by John Q. Ericson Title: Sixty Studies, op. 5 for High Horn, Books I \& 2

Composition/Publication Date: 1832/New edition published in 2000

Publisher: Thompson Edition

Range: f\# - f"'

Transposition: None

Number of Etudes: 60

Difficulty: VI

Description of Contents:

This two-volume set is the companion work to Kopprasch's popular Opus 6 etudes. We have both high and low horn studies from Kopprasch, because he prescribed to the division of the horn's range set forth in Louis François Dauprat's 1824 work, Méthode de Cor Alto et Cor Basse. At the time, it was common practice for horn players to specialize in a particular range 
and become either high or low horn players. This version is a reprint of the original, and respects all of Kopprasch's markings, while also being easier to read than the original version. ${ }^{19}$

Transposition suggestions and other editorial markings common in the Opus 6 etudes are left out of this edition.

The etudes are very similar in style to those from the low horn books, and are technically demanding to perform. Many of the studies in the high horn books are either derived from or direct copies of the material in Opus 6. For instance, the first several etudes in Opus 5 utilize the same rhythmic patterns and musical ideas as the corresponding low horn etudes, but vary slightly due to differences in range. All of the etudes in these two volumes accentuate mainly the register from written g' to written c"'. Many of the studies even stretch the range up to a written d'", e'", and $\mathrm{f}^{\prime \prime}$. Also, the etudes become even more technically demanding in terms of rhythm, range, and flexibility in the second volume. The original versions of these volumes may be downloaded for free using IMSLP (imslp.org), but the notes are often difficult to read due to the quality of the print.

Composer: Kopprasch, Georg; edited by Corbin Wagner Title: Kopprasch Down Under: 47 Studies for Low Horn

Composition/Publication Date: 2011

Publisher: Cornopub

Range: C - e-flat"

Transposition: Suggested transpositions include: $\mathrm{C}$ alto or $\mathrm{C}$ basso

Number of Etudes: 47

Difficulty: IV-V

Description of Contents:

18 The publisher refers to this version as an urtext edition. 
In this book, Wagner takes forty-one Kopprasch etudes, with six Müller studies at the end, and adapts them for low horn study. Each study is written in bass clef using old notation, unless new notation is specified. Some of the studies switch between bass and treble clef, but most of them are written completely in bass clef. Wagner retains all of the dynamic and articulation markings written by Kopprasch and Müller, but does change the key of many of the etudes to better suit low horn playing. He encourages students to begin working on these studies by playing everything at a forte dynamic level, which will test whether or not a student's embouchure is correctly set to play low horn.

These studies are more challenging than McCoy's 46 Progressive Etudes for Low Horn, but are not as technically difficult as the low studies by Neuling and Hackleman. All of the etudes in this book will challenge a player's technical facility and flexibility in the low register, as well as the ability to play across register breaks. Wagner includes basic low horn exercises at the back of the book, which isolate certain problem areas, such as articulation, loud and soft dynamics, and playing technical scalar passages. Wagner also suggests that players transpose these studies into either $\mathrm{C}$ alto or $\mathrm{C}$ basso.

Composer: Lewy, Joseph Rudolf Title: 12 Etudes pour le Cor Chromatique et le Cor Simple avec Accompagnement de Piano Composition/Publication Date: 1855/2011

Publisher: EOD eBooks via the Moravian State Library

Range: F - d-flat"'

Transposition: D, E-flat, and E

Number of Etudes: 12

Difficulty: VI

Description of Contents: 
This is an exact reprint of the etudes published by Breitkopf \& Härtel in 1855. It is presented in two volumes, with each volume containing six etudes. In both volumes, the horn part and piano part are bound together in the same booklet. The books are small, $61 / 2 \times 81 / 2$ in size, which means that the print is also small and difficult to read. Plus, the print is not very clear, with staff lines, note stems, and other markings periodically missing at times.

As the title implies, these etudes contain passages for both the natural and valve horns. The studies are to be played using the valves, unless Lewy indicates a change to the hand horn. Lewy specifies the changes between the horns by writing "avec la main" (with the hand), "Cor simple" (natural), or "Cor chromatique" (valve) in the music. Stylistically, these studies are very similar to many of the other horn etude books published around the middle of the nineteenth century (Kopprasch, Gallay, Müller, etc.). All meters are common, and there are no tonal surprises to mention.

Each etude is very challenging, and will test a player's technical proficiency. The music often quickly shifts between the registers, and there are a good deal of fast, virtuosic rhythmic patterns throughout the two volumes. These etudes are also challenging in terms of endurance, especially due to the fact that almost all of the studies contain several written c'"s, and many even stretch the range up to a written d-flat"'. Lewy does exploit the full range of the instrument, but a majority of the etudes accentuate the range from written $g^{\prime}$ to written c'".

Several of the etudes contain multiple transpositions, and Lewy designates whether or not the transposed portions are to be performed using valves or hand technique. One of the etudes, 
Etude $\mathrm{V}$, is actually to be performed using the valves to facilitate the changing of crooks. Many of the studies also include turns, multiphonics, and lip trills. Etude XI is meant to aid in the facility of lip trills and alternates between the use of valves and hand. Bass clef writing using old notation appears in a few of the etudes.

The four editions described in this paper feature a broad range of prices dependent upon the size, format, and supplemental materials provided.

Composer: Lewy, Joseph Rudolf; edited by Thomas Z. Hale Title: 12 Etudes pour le Cor Chromatique et le Cor Simple avec Accompagnement de Piano Composition/Publication Date: 2002

Publisher: Self-published by Thomas Z. Hale

Range: F - d-flat"'

Transposition: D, E-flat, and E

Number of Etudes: 12

Difficulty: VI

Description of Contents:

This is an updated edition of the etudes originally published by Lewy in 1855 . The etudes basically remain the same, except that Hale revises many of the articulation markings. The horn part and piano part also appear in separate spiral bound books, and the print is much easier to read than the original version. All bass clef writing in this edition appears in new notation. For a more detailed discussion of the content and issues concerning these etudes, please refer to the annotation for the reprint of Lewy's original document published by EOD eBooks. This edition is available on demand through Dr. Hale. For more information, please contact Dr. Hale at whaleherd@gmail.com.

Composer: Lewy, Joseph Rudolf; edited by William O'Bannion

Title: 12 Etudes pour le Cor Chromatique et le Cor Simple avec Accompagnement de Piano 
Composition/Publication Date: 2002

Publisher: Self-published/O'Bannion Music

Range: F - d-flat'"

Transposition: D, E-flat, and E

Number of Etudes: 12

Difficulty: VI

Description of Contents:

This is yet another edition of Lewy's etudes published approximately at the same time as Hale's version. Unlike Hale's publication, O'Bannion's version has the horn and piano parts bound together in the same spiral bound book. Both of these editions were reviewed together in the February 2003 publication of The Horn Call. ${ }^{20}$ As William Scharnberg writes in his review, this edition is accompanied by "a CD of the etudes performed on a synthesizer, with accompaniment, and a floppy disk synthesized version of the piano accompaniments." ${ }^{21}$ For the etudes that contain transposition, O'Bannion includes an alternate F Horn version. Unlike Hale's version, notation size in this edition is not consistent, which does make some of the etudes difficult to read. Bass clef writing is also present, and is notated using new notation. This edition is no longer available through O'Bannion Music, but may be purchased through Pender's Music at the writing of this document.

Composer: Lipsius, Fred; edited by John Clark

Title: Reading Key Jazz Rhythms

Composition/Publication Date: 1997

Publisher: Advance Music

Range: F - a"

Transposition: None

20 William Scharnberg. "Review: 12 Etudes pour le Cor chromatique et le Cor simple avec accompagnement de Piano (Thomas Z. Hale and William N. O'Bannion).” The Horn Call 33, no. 2 (February 2003): 83-84.

21 William Scharnberg. "Review: 12 Etudes pour le Cor chromatique et le Cor simple avec accompagnement de Piano (Thomas Z. Hale and William N. O’Bannion).” The Horn Call 33, no. 2 (February 2003): 84. 
Number of Etudes: 24

Difficulty: III-IV

Description of Contents:

This book is accompanied by a compact disc, which provides recorded examples of the etudes, as well as a rhythm section accompaniment for each etude. Lipsius includes an introduction that discusses the etudes, talks about how to use the compact disc, and explains important jazz elements found in the studies. The jazz elements that he discusses include ornaments, jazz rhythms, rhythmic displacement, swing eighth notes, and jazz phrasing.

There are two versions for each etude. One is the etude proper, while the other is what Lipsius calls a Guide Tone Version. These are simplified versions of the etude that limit the range of the etude, while still allowing the student to hear and play the most important notes in each chord progression, typically the third or seventh of each chord. These two versions may also be performed together as a duet without the accompaniment on the compact disc. The etudes are written in common jazz keys and contain jazz chord symbols, allowing students the opportunity to explore improvisation using the rhythm section accompaniment on the compact disc. The jazz chord symbols include the typical major and minor triads and seventh chords, as well as the more complex seventh, ninth, half-diminished, and diminished chords. All of the etudes are one or two pages in length, and each is based on a standard jazz tune or popular jazz style. Each etude is also based on a particular rhythmic figure, which Lipsius denotes in the top left hand corner of the page. 
These etudes are all tonal and incorporate basic key signatures. The studies may be rhythmically challenging due to the presence of jazz rhythms, syncopation, and rhythmic displacement. Most of the etudes stay in the middle register of the horn, with only a few venturing into the upper register. The one written $\mathrm{F}$ that occurs is actually notated as a written $\mathrm{f}$ with an " $8 \mathrm{vb}$ " notation. If played disregarding the "8vb" notation, the range would change from $\mathrm{F}-\mathrm{a}$ " to $\mathrm{e}-\mathrm{a} "$

Composer: Manous, Carlyle

Title: 53 Studies in Rhythm in Treble Clef

Composition/Publication Date: 1971/1999 ${ }^{22}$

Publisher: RM Williams

Range: a - g"

Transposition: None

Number of Etudes: 53

Difficulty: III-V

Description of Contents:

The etudes in this book are designed to aid students in reading and recognizing rhythmic patterns, and focus on the following rhythmic aspects: dotted rhythms, syncopation, two against three and other combinations, compound meter, mixed meter, shifted accents and rests, three and five notes in a beat or half a beat, tied notes, and mixed sixteenth and thirty-second notes. Since these studies focus on rhythm, markings concerning range and expression are kept at a minimum, so as to not distract the player from the rhythmic aspects presented in each etude. The studies are grouped together according to the corresponding rhythmic issues, and tend to concentrate on one aspect at a time. For instance, Etude Nos. 1 through 12 focus on dotted rhythms, while Nos. 13

22 This work was originally self-published by Manous in 1971, but is now available through RM Williams Publishing. 
through 19 deal with syncopation, and so forth. Certain etudes are written as duets in order to accentuate certain issues, such as playing dotted rhythms against sixteenth notes or sixteenth notes against thirty-second notes. This book is intended to be used by all treble clef instruments, not just horn players. There is also a bass clef version available through RM Williams Publishing priced at $\$ 26$.

Composer: Martin, Jean-Louis

Title: 20 Études pour Cor en fa

Composition/Publication Date: 2000

Publisher: Billaudot

Range: g - e"

Transposition: None

Number of Etudes: 20

Difficulty: II

Description of Contents:

These are easy etudes meant for young, intermediate level horn students. The etudes contain basic quarter and eighth note rhythms, are written in familiar simple and compound meters, and include key signatures with no more than two sharps or flats. Each etude is around a half a page in length, except for the last two, which are a full page in length. All of the etudes are accompanied by a suggested tempo marking. Martin varies the tempo and style of each etude, and includes contrasting dynamic and articulation markings.

Composer: Matosinhos, Ricardo

Title: 12 Jazzy Etudes for Horn

Composition/Publication Date: 2010

Publisher: Phoenix Music

Range: F - c"'

Transposition: None

Number of Etudes: 12

Difficulty: VI 


\section{Description of Contents:}

These etudes are dedicated to the Russian jazz horn player Arkady Shilkloper, and are intended to be challenging, while still remaining fun and humorous. Matosinhos utilizes different modes and scales for each etude, and incorporates a wide array of meters. Many of the etudes contain compound and asymmetrical meters, as well as mixed meter. The rhythms are complex, and are often difficult to read due either to the meter or the way a particular rhythm is written (i.e., the way in which certain notes are beamed or grouped together). Matosinhos also incorporates the use of many extended techniques for the horn, including lip trills, stopped horn, playing strictly using the harmonic series, and multiphonics. He provides tempo markings for each etude, and bases each study on a certain mode, extended technique, or rhythmic aspect. For instance, Etude No. 1 incorporates added values, No. 4 utilizes quarter tones, No. 9 focuses on stopped horn and the quickness of the right hand, and No. 12 is built around horn chords, which are produced using multiphonics. Etude No. 11 is especially interesting, because it is based on the second movement from Ligeti's Trio for Horn, Violin, and Piano. This etude is not meant to be transposed, but to be played using the valves to switch between the different harmonic series on the horn. Matosinhos incorporates the following key areas in this etude: F, E, E-flat, D, D-flat, B, B-flat, A, A-flat, G, and F\#.

Composer: McCoy, Marvin M.

Title: 46 Progressive Exercises for Low Horn

Composition/Publication Date: 1986

Publisher: McCoy's Horn Library

Range: c - e"

Transposition: None 
Number of Etudes: 46

Difficulty: II-IV

Description of Contents:

This book is intended to introduce young, intermediate level students to low horn playing and bass clef writing. The first few pages of etudes are easy, containing simple eighth, quarter, half, and whole note rhythms and never extend the range lower than a written $\mathrm{f}$. The studies do progress in difficulty, but the rhythms never become complex and should be suitable for advanced high school and young college students. All of the studies are tonal, and the key signatures never venture beyond four sharps or flats. Most of the studies are written in bass clef, although there are several that stay in treble clef or shift between the two. The bass clef studies are written using new notation, unless old notation is specified. McCoy also includes suggested tempo markings for most of the etudes. All of the exercises vary in style, and a few of the studies include valve trills.

Composer: Merck, J. H.

Title: 24 Etudes pour Cor

Composition/Publication Date: 1985

Publisher: Hans Pizka

Range: c - d"'

Transposition: None

Number of Etudes: 24

Difficulty: IV-VI

Description of Contents:

The etudes are tonal, and are similar in style to the works of Kopprasch and Gallay. These studies progress in difficulty concerning technical proficiency and range, withholding the written c"' until Etude No. 12. At the beginning, the rhythms are limited to eighth, quarter, and half 
notes, but then sixteenth and thirty-second note rhythms are progressively introduced, as well as passages that are fast and more technically challenging. There is a good mixture of etudes that are fast and technical, and those that are more melodic and present artistic challenges, such as varying articulations, accents, rubato, and contrasting dynamics. Merck also tends to base each etude on a certain rhythmic, artistic, or horn related aspect. This includes attacks (articulation/accents), large leaps, rubato, lyrical or legato playing, triplets, syncopation, lip trills, echo horn and stopped horn, and other rhythmic or technical issues. The final etude, No. 24, reviews some of the more technically challenging sections presented throughout the book.

Composer: Miles, Patrick

Title: Low Horn Etudes and Drills for the Intermediate Horn Player

Composition/Publication Date: 2009

Publisher: Really Good Music

Range: E-flat - $\mathrm{f}^{\prime}$

Transposition: None

Number of Etudes: 22

Difficulty: IV

Description of Contents:

This book is meant for those incoming freshmen horn players at the collegiate level, who have had little or no experience playing in the low register of the horn. Miles includes a fingering chart covering low register notes, and also provides five drill exercises that focus on stability, dynamic range, articulation, and scalar patterns in the low register. Exercise 5 is based on the final three notes of the first horn solo from Till Eulenspiegel. Some of the etudes are taken from the works of Concone and Endresen, and have been transposed into different keys. Also, all of the etudes are written in bass clef using new notation. 
The etudes are tonal and are not rhythmically complex. The rhythms mostly consist of eighth, quarter, half, and whole notes, while more difficult rhythms are limited to triplets and sixteenth notes. All of the studies are written in contrasting styles, and contain artistic elements, such as variations in articulation, dynamic contrasts, and issues concerning phrasing. The most challenging part of this book is the fact that many of these works require the student to frequently play notes below the written c. Miles also recommends that students purchase and work through Randy Gardner's book, Mastering the Horn's Low Register.

Composer: Miller, Brett

Title: "45 Concert Etudes on the Themes of Richard Strauss, Gustav Mahler, and Johannes Brahms"

Composition/Publication Date: 2007

Publisher: University of Maryland

Range: E-flat - c\#"'

Transposition: E, E-flat, D, C, B, B-flat basso

Number of Etudes: 45

Difficulty: IV-VI

Description of Contents:

The etudes in this dissertation are not presented in a separate chapter or appendix, but appear throughout the actual text within the document. Miller divides the studies among three chapters, with each chapter focusing on a specific composer. Each etude typically ranges from a half a page to a page in length. All of the studies are tonal, or at least contain tonal centers, except for the etude based on Salome, which reflects the opera's harmonic ambiguity. These etudes are technically challenging, containing fast passages that traverse the entire register of the horn. Some of the etudes are also written in odd meters, such as $3 / 8,5 / 8$, and $7 / 8$. The etudes are contrasting in style, and offer artistic challenges, which include contrasting articulations, 
dynamics, and phrasing. Most of these works contain notes in the upper register above a written $\mathrm{g}^{\prime \prime}$, and there is bass clef writing in both old and new notation.

As the title implies, Miller bases each etude on a specific theme or motive from a particular work. The Strauss etudes are based on themes from Don Juan, Sinfonia Domestica, Salome, Till Eulenspiegel, Don Quixote, Death and Transfiguration, Ein Heldenleben, Horn Concerto No. 1, Horn Concerto No. 2, and Alpine Symphony. The Mahler etudes are derived from the following works: Symphony No. 1, Symphony No. 4, Symphony No. 5, Symphony No. 3, Symphony No. 7, and Symphony No. 9. The Brahms etudes are based on motives and sections from Symphony No. 4, Academic Festival Overture, Piano Concerto No. 2, Serenade No. 1, Symphony No. 1, Symphony No. 2, Symphony No. 3, and Trio, Op. 40. These studies are also published by Horn Dog Publishing (Silver Springs, MD). They are grouped by composer and divided into three books, which are typically priced around $\$ 12$ per book.

Composer: Oliveros, Pauline

Title: The Oliveros Interval Studies

Composition/Publication Date: Written in 1959/Published in 2002

Publisher: I-Ching Music

Range: A\# - c'"

Transposition: None

Number of Etudes: 15

Difficulty: V-VI

Description of Contents:

These studies were originally written in 1959 at the request of S. Earl Saxton, former hornist of the San Francisco, Oakland, and Pittsburgh Symphonies. Each etude focuses on specific intervals, which include minor seconds, major seconds, augmented seconds, minor 
thirds, major thirds, perfect fourths, and perfect fifths. The first few etudes use only two types of intervals, while later etudes include up to five types of intervals. The intention of this work is to provide studies that address the type of disjunct and contrapuntal lines that are prevalent in many twentieth-century compositions. These etudes live up to this intention, while remaining both challenging and artistically rewarding. The range and rhythmic requirements are demanding, and many of these etudes are written in simple and compound meters that constantly shift. Etude No. 6 is unmetered. Several of these studies include bass clef writing in new notation, and Etude No. 12 incorporates the use of stopped horn.

Composer: Proust, Pascal

Title: 25 Études sur des soli d'orchestre (avec transposition)

Composition/Publication Date: 2002

Publisher: Éditions Combre

Range: $\mathrm{G}$ - a"

Transposition: C basso, B, C, D, E-flat, E, G

Number of Etudes: 25

Difficulty: V

Description of Contents:

These studies are meant to aid students in becoming more familiar with important orchestral horn parts. Each study is based on a particular orchestral or operatic piece, and includes important horn motives from that piece in the original key. Proust also adds new material to each study, which is similar in style to the original material. Original motives are marked by the use of brackets. Proust generally includes important motives from all four horn parts. 
Many of these etudes require transposition, while Etudes 5, 6, 7, and 21 contain multiple transpositions. Rhythmically, these studies are not overly challenging, except for those that include thirty-second note runs or sequences of a double dotted eighth note followed by a sixteenth note. All of the studies present artistic and technical challenges that are unique to each corresponding orchestral piece. These challenges include dynamics, articulation, tempo fluctuation, and performing each etude in the correct style. Proust also includes lip trills and turns.

The list of orchestral pieces used in this work is as follows:

J.S. Bach, Cantata BWV 65

L. van Beethoven, Overture to King Stephen

L. van Beethoven, Violin Concerto

L. van Beethoven, Symphony No. 3

L. van Beethoven, Symphony No. 8

G. Bizet, Carmen

J. Brahms, Piano Concerto No. 2

J. Brahms, Serenade No. 1

A. Bruckner, Symphony No. 7

A. Dvorak, Serenade

F. Liszt, Tasso

G. Mahler, Symphony No. 5

F. Mendelssohn, Symphony No. 3

G. Rossini, Overture to The Turk in Italy

G. Rossini, The Barber of Seville

I. Stravinsky, Petrushka

P.I. Tchaikovsky, Symphony No. 5

G. Verdi, Don Carlos

R. Wagner, Lohengrin

R. Wagner, Siegfried Idyll

R. Wagner, Götterdämmerung

R. Wagner, Die Meistersinger

C.M. von Weber, Euryanthe

C.M. Von Weber, Overture to Der Freischütz 
Composer: Proust, Pascal

Title: 40 Études de Style

Composition/Publication Date: 2004

Publisher: Éditions Combre

Range: c - a"

Transposition: None

Number of Etudes: 40

Difficulty: III-IV

Description of Contents:

Each etude in this work is written with a specific style or characteristic quality in mind.

Proust covers a wide variety of styles ranging from nocturne to fanfare. He incorporates even lesser used styles, such as ragtime, blues, polka, and the Charleston. The studies are typically a half of a page or shorter in length. All of the etudes are tonal, and the key signatures never contain more than three sharps or flats. Several of these studies may be challenging for younger, inexperienced students, especially the etudes containing dotted sixteenth note rhythms, as well as the rhythms with a double dotted eighth note followed by a sixteenth note. The studies are also written in common time signatures, except for the three that are written in $2 / 2,3 / 8$, and $12 / 8$ respectively. Etude No. 14, which is written in the style of an alphorn solo, is unmetered and uses fermatas to separate each melodic idea.

All of the etudes are accompanied by a suggested tempo marking, while some studies also contain markings that designate fluctuations in tempo. These markings include ritardando, rallentando, allargando, and leggiero. Each etude also presents artistic challenges specific to its characteristic style, which allows Proust to explore the use of a wide variety of dynamic ranges and articulations. There is also bass clef writing in new notation. 
Composer: Randall, Ronald F.

Title: Twenty Etudes for the Advanced Horn Student

Composition/Publication Date: Copyrighted 1985/Published in 2000

Publisher: I Ching Music

Range: G - d"'

Transposition: None

Number of Etudes: 20

Difficulty: V-VI

Description of Contents:

All twenty studies are written in contrasting styles and are technically challenging, yet artistically rewarding. Randall includes a few sentences before each etude that explain the musical concepts and technical aspects that a player will need to consider while working through a particular study. The etudes themselves are generally a page to two pages in length and are intended to aid in the development of range, accuracy, and endurance. These studies are rhythmically challenging due to the inclusion of complex rhythms, and Randall often shifts between simple and compound meter in many of the etudes. He also includes grace notes, turns, and valve trills. The etudes are not harmonically innovative and contain definite tonal centers. All of the studies include wide intervallic leaps and also require a great deal of playing in the upper register of the horn above a written g". Randall mentions that players should strictly follow all articulation, phrase, and tempo markings. Some of the etudes also contain bass clef writing in new notation. The preface mentions that four duets will be included as a bonus, but these works are not found in this edition. Also, the book contains some awkward page turns, and many of the studies are difficult to read due to spacing and font issues.

Composer: Ranieri, Vincenz; edited by Kathleen Kenyon Hopper 
Title: "A Performance Edition of Thirty Instructive and Melodic Exercises for French Horn by Vincenz Ranieri",23

Composition/Publication Date: $2007^{24}$

Publisher: University of North Carolina at Greensboro

Range: D - c\#"'

Transposition: None

Number of Etudes: 30

Difficulty: V

Description of Contents:

The performance edition of Ranieri's etudes appears as chapter 4 of this dissertation, and Hopper gives a detailed description of the contents of each etude at the end of chapter 2. Hopper also describes the changes made to each study, which include modifying the range of the scalar exercises that precede each etude; changing phrase, slur, articulation, and dynamic markings; correcting typographical errors and other aesthetic changes, such as courtesy accidentals and altering certain note beamings. All of the etudes are tonal, and are a page in length. These etudes are technically challenging, and contain fast passages that shift quickly between different registers. Ranieri's studies also present many artistic challenges that include fluctuations in tempo, phrasing, and contrasting articulations and dynamics. Many of the etudes contain uncommon key signatures, such as G-flat major, C-flat major, F\# major, D\# minor, and C\# major. There are also many double sharps that appear throughout the studies, and bass clef notes are written in old notation. This new edition was compiled and edited using Finale software.

Composer: Runge, Jürgen

Title: Etüdien für Horn und Piano

Composition/Publication Date: 2007

23 This dissertation is available as a pdf download through ProQuest Dissertations and Theses.

24 Ranieri's Thirty Instructive and Melodic Exercises for French Horn have been out of print in the United States since the mid 1900s. 
Publisher: Friedrich Hofmeister

Range: $f$ - f"

Transposition: None

Number of Etudes: 12

Difficulty: I-III

Description of Contents:

Runge's work is intended for beginning to intermediate horn and piano students. All of the etudes have titles and are meant to be short character pieces. Neither the piano part nor horn part is very difficult, and the range requirements should be manageable for young horn students. All of the etudes are very short, with the longest one being just over a half page in length for the horn. The key signatures never contain more than three flats and most of the etudes are not very demanding in terms of rhythm, except for the etude titled "Bulgarischer Tanz." This etude constantly shifts between $7 / 8$ and $4 / 4$, which may be tricky for younger students who are unfamiliar with complex meters.

Composer: Schantl, Josef

Title: 92 Beginning Exercises for Valved Horn/92 Anfängerübungen für Ventilhorn Composition/Publication Date: $1985^{25}$

Publisher: Hans Pizka

Range: F - b-flat"

Transposition: None

Number of Etudes: 92

Difficulty: I-IV

Description of Contents:

The first few pages of exercises and etudes are very short and are meant to guide the beginning hornist through the octaves ranging from $\mathrm{c}$ to $\mathrm{c}$. The rhythms within these first few pages are very basic, and Schantl even provides fingerings for all of the notes. It should be noted

25 Hans Pizka published a revised version of this work in 2012. 
that the fingerings that Schantl provides are for the F horn. The etudes progressively increase in difficulty throughout the book, meaning that each successive etude expands the range and adds new technical or rhythmic demands. Schantl also supplies an etude in every key. Since there are ninety-two exercises, the progression of difficulty is slow, but these etudes cover a lot of material and address a wide range of styles and technical aspects. This includes etudes that specifically address certain intervals, fast staccato playing, flexibility, scalar patterns, and even lip trills. All of the etudes are either in $2 / 4,3 / 4,4 / 4$, or $6 / 8$ time. A few of the later etudes employ turns and grace notes, and many of the etudes contain bass clef writing in old notation. It should also be mentioned that all of the etudes/exercises are printed in hand-written, manuscript style. This makes it difficult to read many of the etudes, especially those that include ledger lines.

Composer: Schantl, Josef and Milan Yancich

Title: Etudes for the Natural Horn and Hand Horn Exercises

Composition/Publication Date: 2005

Publisher: Wind Music Publications

Range: $C$ - c'"

Transposition: None

Number of Etudes: 63

Difficulty: IV-VI

Description of Contents:

A preface written by Milan Yancich discusses hand horn technique with a specific emphasis upon the use of hand-stopping. This book is essentially divided into two sections. The first section consists of twenty natural horn etudes written by Josef Schantl. These etudes are meant to promote a full sound and facility when playing through the open notes of the $\mathrm{F}$ horn. The first four etudes are comprised of whole, half, and quarter notes, while the etudes that follow 
quickly progress in difficulty by adding shorter note values and more complicated rhythms. The first few etudes focus on basic principles, such as a good sound, dynamics, staccato playing, and accents. Schantl often writes an etude and then provides subsequent variations on the basic rhythmic or melodic theme of that etude. For example, Etude 8 has four different variations that differ slightly in rhythm, articulation, and tempo. Many of the etudes are written in compound meters, and the rhythms in later etudes become more intricate and technically demanding. A majority of these etudes also contain many leaps of an octave or more that require a great deal of flexibility and technical facility.

The second section is made up of hand horn exercises written by Yancich and Henri Kling. It begins with two diagrams, written by Yancich and Kling respectively, that give examples of how to perform stopped notes on the F horn. The first several exercises are focused on the performance of specific diatonic and chromatic intervals, while the ones that follow are more artistic in nature. The exercises by Kling and Yancich are fairly short, but still contain valuable material.

Composer: Shaw, Lowell E.

Title: Just Desserts - Frippery Style

Composition/Publication Date: 1999

Publisher: The Hornists' Nest

Range: c - a-flat"

Transposition: C, E-flat

Number of Etudes: 12

Difficulty: IV-V

Description of Contents: 
The etudes in this book are similar in style to Shaw's Quipperies, Fripperies, Tripperies, and Bipperies. These works are not meant to be used to instruct horn players in the performance of jazz, but they do contain jazz rhythms and other elements that may be helpful for those interested in that style of music. Shaw includes a preface that discusses each etude, addressing the styles, nuances, and rhythms found in each specific work. The styles used for these studies range from swing to Dixieland jazz. All of the etudes are a page in length, and written in basic keys. The studies are also written in common simple and compound meters, except for the two etudes written in $12 / 8$ and $3 / 2$. The rhythms in these works are meant to be challenging, especially due to the presence of syncopation and rhythmic displacement. Each etude is accompanied by a suggested tempo marking, and Shaw includes difficult stopped-horn passages in a few of the studies. These works are suitable for both solo and instructional purposes, and there is also an Optional Bass Part sold separately, which allows these etudes to be performed as duets.

Composer: Thompson, Timothy F.

Title: "Extended Techniques for the Horn: An Historical Overview with Practical Performance Applications."26

Composition/Publication Date: 1997

Publisher: University of Wisconsin-Madison

Range: F - c"'

Transposition: None

Number of Etudes: 24

Difficulty: IV-VI

Description of Contents:

26 This dissertation is available as a pdf download through ProQuest Dissertations and Theses. 
Thompson's dissertation is divided into six chapters, with each chapter focusing on specific extended techniques. The techniques discussed in this document include explosive and indistinct attacks, releases, pulsation, vibrato, flutter tongue, growling, indefinite pitch, different types of glissandi, stopped horn, other muting techniques, quarter tones, and half-valve effects. The etudes are never longer than a page, and appear at the end of each chapter. Most of the studies are chromatic, or consist of a combination of intervallic patterns that are not tonally related. These etudes are very challenging due to the many extended techniques that are covered in this work. The sections dealing with muting techniques are especially difficult, due to the inclusion of quick mute changes while performing fast technical passages. The stopped horn section also includes echo horn, and the mute section contains an etude that requires a "Glass Mute," which is an empty bottle. Thompson thoroughly explains and gives examples of the techniques within each chapter, and even includes drill material and exercises for students to work through before moving on to the etudes. Thompson also provides suggested fingerings for many of the quarter tone and half-valve sections.

Composer: Uber, David Title: Early Rhythmic Studies for Horn

Composition/Publication Date: 1985

Publisher: Touch of Brass Music

Range: g - b-flat"

Transposition: None

Number of Etudes: 31

Difficulty: IV

Description of Contents: 
Even though the etudes in this book gradually progress in difficulty, the work as a whole should be accessible for most advanced high school and young collegiate horn players. All but four studies are accompanied with a suggested tempo marking, and the majority of these etudes are a page in length. Etudes VI and XI are two pages in length. Uber explores a number of key areas and time signatures. Several of these etudes are written in compound time signatures that younger students may not be familiar with, such as $5 / 8$ and $7 / 8$. A few of them are also written in cut time. There is a good mixture of melodic and technical etudes that are contrasting in style. Three of these etudes are written in waltz style. Since these etudes are meant for more inexperienced horn students, the range requirements and rhythmic patterns found throughout the book are moderate.

Composer: Uber, David

Title: Solo Etudes for Horn

Composition/Publication Date: 2001

Publisher: The Hornists' Nest

Range: c - c'"

Transposition: None

Number of Etudes: 12

Difficulty: IV-V

Description of Contents:

All of the etudes in this book are written in contrasting styles, with many variations in tempo, meter, articulation, and dynamics. Each etude is tonal, and the key signatures do not contain more than five sharps. Uber employs the use of both simple and compound meter, including cut time and 5/8. Each etude is accompanied by a suggested tempo marking, but Uber does mention that these tempo markings are not definitive and encourages the use of rubato. 
Some of these studies are rhythmically challenging and contain intervallic leaps that will test a player's flexibility. These works also offer many artistic challenges due to the contrasts in style, articulation, and dynamics. Etude I is the only study to cover the entire $\mathrm{c}-\mathrm{c}^{\prime \prime}$ range, while the rest of the etudes are moderate in range, but do often venture above a written g" at the top of the staff. These works are intended to be instructional, but may also be used as unaccompanied pieces on a recital. Uber suggests that two or more etudes of contrasting style, tempo, and tonality be programmed together. He also mentions that students may transpose these studies into any key.

Composer: Zarzo, Vicente Pitarch Title: 10 Estudios para Trompa: Sobre una idea de Bernard Krol

Composition/Publication Date: 1995

Publisher: PILES

Range: G - c'"

Transposition: None

Number of Etudes: 10

Difficulty: VI

Description of Contents:

As mentioned in the title, the etudes in this book are based on an idea of the German composer, Bernhard Krol. Zarzo's studies are very challenging and require a great deal flexibility and stability in all registers. The etudes range from a page to three pages in length and each one is given a suggested tempo marking, even though many of the etudes contain drastic fluctuations in tempo. Meter constantly shifts within each etude, and Zarzo incorporates the use of both simple and complex meter. This book is filled with challenging rhythms, odd intervallic leaps, and technically demanding passages. Players will need good endurance and a stable high register 
to perform these etudes. Not only are these studies technically demanding, but they also require a great deal of attention in regard to dynamics and artistic interpretation. Zarzo is very specific with his dynamic markings and constantly shifts quickly between soft and loud dynamics. The etudes do modulate frequently, but Zarzo does not use key signatures. This work also includes stopped horn writing in the high register, turns and grace notes, lip trills, and bass clef writing in old notation.

Composer: Zarzo, Vicente Pitarch Title: 12 Estudios para Trompa Natural

Composition/Publication Date: 1995

Publisher: PILES

Range: c - c"'

Transposition: All studies are for natural or hand horn in F Number of Etudes: 12

Difficulty: V

Description of Contents:

As the title explains, these studies are intended to aid horn players in developing proficiency on the hand horn. These etudes are not easy, even though the first three studies are strictly limited to notes within the F harmonic series. All of the etudes cover an expansive range and frequently go up to the top of the range. Beginning with Etude VI, Zarzo adds more and more non-harmonic tones that require a good understanding of hand-stopping technique.

Rhythmically, these studies are fairly straightforward, but the hand horn requirements add to the difficulty level of these works. All of the studies, except for Etude XI, are a page in length, and they are all contrasting in style. Etude XI is two pages long. These etudes also contain turns, lip trills, and glissandi. Etude XI includes the use of multiphonics in the final two chords of the 
study. Zarzo gives instructions for the performance of these chords, telling players to sing the fifth of the penultimate chord and the third of the final chord. Old notation bass clef writing is used for only one note, which is written c. 


\section{Chapter 3: Bibliographical Listing of Etude Books without Annotations}

Allen, Eric. Success in All Keys for Horn. Batavia, IL: Better Bands and Orchestras, 2009.

A review of this work is available in the February 2011 edition of The Horn Call, pp. 7778.

Allen, Eric. Low Range Studies for Horn. Batavia, IL: Better Bands and Orchestras, 2009.

A review of this work is available in the February 2011 edition of The Horn Call, pp. 7778.

Burdick, Richard. Accuracy Studies for the French Hornist. Regina, SK, Canada: I Ching Music, 2008.

A review of this work is available in the February 2011 edition of The Horn Call, p. 78.

Cottrell, David. Studies in Ancient Irish Song. Salem, CT: Cimarron, 2006.

Damm, Peter. Studien für Horn. Halberstadt, Germany: Musikverlag Bruno Uetz, 2006.

A review of this work is available in the February 2007 edition of The Horn Call, pp. 8182.

Domnich, Heinrich. Selected Etudes for Two Horns from Methode de Premier et Second Cor. Edited and Arranged by Gregory Danner. Owensboro, KY: Medici, 1990.

A review of this work is available in the April 1991 edition of The Horn Call, p. 66.

Koetsier, Jan. 13 Études Charactéristiques, op. 117. Crans-Montana, Switzerland: Editions Marc Reift, 2000.

Lewy, J.R. 12 Etudes por le Cor chromatique et le Cor simple avec accompagnement de Piano. Edited by Michel Garcin-Marrou. Paris: Gérard Billaudot Éditeur, 2008.

This edition is presented in two volumes. Please refer to the annotation for the reprint of Lewy's original document on pp. 39-41 of this document for general information regarding these etudes.

Marchesi, Mathilde. 24 Volkalisen für Horn. Edited by William S. Fatch. Hofheim-Leipzig, 
Germany: Friedrich Hofmeister, 1997.

A review of this work is available in the May 2001 edition of The Horn Call, pp. 81-82.

Muth, Fritz. 10 Uebungen zur Bildung d. Gelaeufigkeit op.51a. Kirchheim, Germany: Hans Pizka, 1985.

Orval, Francis. Treatise-Method and Exercises \& 21 Etudes. Crans-Montana, Switzerland: Editions Marc Reift, 2007.

A review of this work is available in the October 2007 edition of The Horn Call, pp. 8384.

Proust, Pascal. 15 Pièces en forme d'études. Paris: Éditions Combre, 1996.

A review of this work is available in the February 1999 edition of The Horn Call, p. 88.

Suttner, Josef. Praktische Studien für Horn: based on the introduction to the stage works of Richard Wagner. Edited by Peter Damm. Halberstadt, Germany: Musikverlag Bruno Uetz, 2006.

A review of this work is available in the May 2007 edition of The Horn Call, p. 93-94. 


\section{Chapter 4: Summary}

There are at least sixty-eight new additions to the etude repertoire that have been published since 1985. Some of these newer works, such as Martin Hackleman's 21

Characteristic Etudes for High Horn Playing and Marvin McCoy's 46 Progressive Exercises for Low Horn, have become very popular and are frequently used by college professors, but this accounts for only a small portion of the repertoire that has been added within the last thirty-six years. These newer additions to the repertoire are seemingly being overlooked, due to the fact that these recent additions are rarely mentioned or recommended in syllabi from some of the major universities across the United States.

Many of the more recent etude books are just as valuable and offer the same kinds of technical and musical rewards as the older literature in new and innovative ways. It is important to be aware of these newer works, because they can potentially be valuable tools for developing reading skills. In addition, some horn players often become complacent or bored, and will need the variety and freshness offered by new compositions in order to continue to improve. There are a number of etude books that focus on middle and low register playing, as well as those that help improve proficiency concerning the extended techniques that are prevalent in both new and standard literature. Last but not least, these books reflect the continually increasing performance expectations placed upon professional horn players, and aid students in preparing for them.

Even though the majority of the books discussed in this document are published in the United States, I was able to find several books published in other countries, such as Australia, 
Canada, and several countries throughout Europe. Most of the etudes in this study were obtained using the ILLiad service through the West Virginia University Libraries, and were supplied by libraries across the United States and Europe. I purchased ten of the books for my own personal collection, and a number of etude books were supplied by Dr. Virginia Thompson. The West Virginia University Libraries ordered the remaining thirteen books that were not available through ILLiad, in order to support future undergraduate and graduate courses in pedagogy and repertoire. Due to time constraints, I was unable to include thirteen of the etude books, because they arrived after my cut off date of March 30, 2012. While writing this document, it was discovered that a student in Portugal, Ricardo Matosinhos, was working on a similar research project. His project covers etude books published from 1950 to 2011, but I am unable to comment on the scope of the information included in his document.

While working on this project, I inadvertently discovered four drill books that I initially believed to be etude books. These books included Practical Exercises for Horn by Lee Bracegirdle, I Ching Interval Studies by Richard Burdick, Flow Studies for Horn by Nancy Sullivan, and Low Horn Flexibility Studies by David Ware. Bracegirdle's book is dedicated to the memory of James Chambers, Principal Horn of the New York Philharmonic from 1946 to 1969 , and consists of drill material that addresses the following areas: articulation, embouchure development, flexibility, endurance, and high register playing. The I Ching Interval Studies and Low Horn Flexibility Studies are both comprised of repeated rhythmic and intervallic patterns that do not allow for melodic or artistic interpretation. The material in Sullivan's Flow Studies for 
Horn is based on the teachings of the trumpet pedagogue Vincent Cichowicz, who served on the faculty of Northwestern University from 1958 to 1998 and was a member of the Chicago Symphony from 1952 until 1974. The description of this book, which mentioned an emphasis on phrasing, led me to assume that the studies were etudes. After receiving the book, I determined that these studies are drill material, because each exercise consists of a specific rhythmic pattern that is repeated at different pitch levels.

Since drill material is beyond the scope of this research project, it would be beneficial for further study to be conducted concerning this body of literature. At the writing of this document, there are no annotated guides that catalogue drill material written or published since 1985 . There have been many valuable drill contributions to our repertoire within the last thirty-six years, and a study of this nature would be very beneficial to both pedagogues and performers. Other recommendations for further study include a future annotated guide to etude books written in 2012 and beyond, as well as annotated guides that catalogue recent contributions to other facets of our repertoire, such as new horn ensemble works, unaccompanied horn solos, and compositions written for horn and piano.

The purpose of this document is to not only provide horn players and teachers with an extensive bibliography of horn etude literature published since 1985 , but to also provide a guide that will help promote the advancement of this literature. This study yielded a wide variety of etude books, ranging from studies written for beginners to those containing virtuosic etudes that exploit the entire range of the instrument. Many of these books were written to address specific 
areas of need, such as reading complex rhythms, lyrical or technical playing, and developing facility in the low and high registers. This text supplies pedagogues and college professors with a resource that allows them to find and incorporate new etude books that will fit the specific needs of particular students. It also provides assistance to those performers searching for new books that address a specific range or technical aspect. 


\section{Bibliography}

Bennett, Travis Andrew. “A Horn Player's Guide: Using Etudes, Solos, and Orchestral Excerpts to Address Specific Technical and Musical Challenges." D.M.A. diss., The University of Alabama, 2003.

Chenoweth, Richard. "Review: Praktische Studien für Horn: based on the introduction to the stage works of Richard Wagner (Josef Suttner). The Horn Call 37, no. 3 (May, 2007): 9394.

Culbertson, Robert Merrill, Jr. "The Kopprasch Etudes for Horn." D.M.A. diss., University of Texas, 1990.

Dean, David. "Improving Left-Hand Finger Dexterity: Etudes for French Horn.” D.M.A. diss., University of Northern Colorado, 1993.

Deats, Carol. "Toward a pedagogy of extended techniques for horn derived from Vincent Persichetti's 'Parable for Solo Horn,' Opus 120.” D.M.A. diss., Texas Tech University, 2001.

Faust, Randall E. "Review: 12 Preludes for Unaccompanied Horn (Yehezkel Braun)." The Horn Call 17, no. 2 (April 1987): 79.

Faust, Randall E. "Review: 21 Characteristic Etudes for High Horn Playing and 34 Characteristic Etudes for Low Horn Playing (Martin Hackleman)." The Horn Call 16, no. 2 (April 1986): 87-88.

Hansen, Jeremy Christian. "A Creative Pedagogical Approach to Hindemith's Music for Horn and Piano with Thirty Progressive Etudes.” D.M.A. thesis, University of Iowa, 2009.

Hopper, Kathleen Kenyon. "A Performance Edition of Thirty Instructive and Melodic Exercises for French Horn by Vincenz Ranieri.” D.M.A. diss., University of North CarolinaGreensboro, 2007.

Howe, Marvin C. "A Critical Survey of Literature, Material, Opinions, and Practices Related to Teaching the French Horn.” Ph.D. diss., University of Iowa, 1966.

Koerselman, Herbert LeRoy. "An Annotated Bibliography of Brass Study Materials which Deal with Performance Problems Encountered in Contemporary Music.” D.M.A. diss., University of Iowa, 1976. 
Miller, Brett Edward. "45 Concert Studies on the Themes of Richard Strauss, Gustav Mahler and Johannes Brahms.” D.M.A. diss., University of Maryland, 2007.

Pherigo, Johnny Lee. "A Critical Survey of Materials and Practices Related to Teaching the Horn, 1965-1985.” D.M.A. diss., University of Illinois at Urbana-Champaign, 1986.

Pherigo, Johnny Lee. "Horn Study Materials: A Survey of New and Reissued Publications Available in the United States with a 1965-1985 Copyright." The Horn Call Annual no. 2 (1990): 2-48.

Powers, Jeffrey. "Review: Solo Etudes for Horn in F (David Uber)." The Horn Call 32, no. 3 (May 2002): 82.

Scharnberg, William. "Review: 10 Estudios para Trompa: Sobre una idea de Bernard Krol, op. 7 (Vicente Pitarch Zarzo)." The Horn Call 28, no. 1 (November 1997): 80.

Scharnberg, William. "Review: 12 Estudios para Trompa Natural, op. 6 (Vicente Pitarch Zarzo).” The Horn Call 28, no. 1 (November 1997): 80.

Scharnberg, William. "Review: 12 Etudes pour le Cor chromatique et le Cor simple avec accompagnement de Piano (Thomas Z. Hale and William N. O'Bannion)." The Horn Call 33, no. 2 (February 2003): 83-84.

Scharnberg, William. "Review: 15 Pièces en forme d'études (Pascal Proust)." The Horn Call 29, no. 2 (February 1999): 88.

Scharnberg, William. "Review: 20 Études Concertantes sur 5 Notes (Éric Hulin)." The Horn Call 29, no. 4 (August 1999): 87.

Scharnberg, William. "Review: 20 Etudes pour cor en fa (Jean-Louis Martin)." The Horn Call 31, no. 1 (November 2000): 83.

Scharnberg, William. "Review: 24 Volkalisen für Horn (Mathilde Marchesi)." The Horn Call 31, no. 3 (May 2001): 81-82.

Scharnberg, William. "Review: 85 Melodic and Rhythmic Studies (James Irwin)." The Horn Call 21, no. 2 (April, 1991): 65-66. 
Scharnberg, William. "Review: Studies for Horn (Concone, Giuseppe; edited by Ashworth)." The Horn Call 29, no. 1 (November 1998): 93.

Scharnberg, William. "Review: Selected Etudes for Two Horns from Methode de Premier et Second Cor (Heinrich Domnich).” The Horn Call 21, no. 2 (April, 1991): 66.

Snedeker, Jeffrey. "Review: Fourteen Concert Etudes on the Themes of Richard Strauss, Fifteen Concert Etudes on the Themes of Johannes Brahms, and Sixteen Concert Etudes on the Themes of Gustav Mahler (Brett Miller)." The Horn Call 38, no. 3 (May, 2008): 75-76.

Snedeker, Jeffrey. "Review: 18 Contemporary Etudes for Horn (Richard E. Brown)." The Horn Call 38, no. 2 (February, 2008): 78.

Snedeker, Jeffrey. "Review: Twenty Etudes for the Advanced Student (Ronald F. Randall)." The Horn Call 35, no.2 (February 2005): 73-74.

Snedeker, Jeffrey. "Review: 25 Études sur des soli d'orchestre (avec transpositions) (Pascal Proust)." The Horn Call 34, no. 1 (October, 2003): 76-77.

Snedeker, Jeffrey. "Review: 40 Études de style pour cor." The Horn Call 35, no. 1 (October 2004): 81.

Snedeker, Jeffrey. "Review: Accuracy Studies for the French Hornist, op. 158 (Richard Burdick)." The Horn Call 41, no. 2 (February 2011): 78.

Snedeker, Jeffrey. "Review: Development Exercises and Etudes for Horn (John Barrows)." The Horn Call 41, no. 1 (October 2010): 79-80.

Snedeker, Jeffrey. "Review: Natural Horn/Valve Horn Technical Etudes: Strengthening Valve Horn Playing through Natural Horn Study (Bruce Atwell). The Horn Call 36, no. 1 (October 2005): 80-81.

Snedeker, Jeffrey. "Review: Studien für Horn (Peter Damm)." The Horn Call 37, no. 2 (February 2007): 81-82.

Snedeker, Jeffrey. "Review: Success in All Keys for horn and Low Range Studies for horn (Eric Allen)." The Horn Call 41, no. 2 (February 2011): 77-78. 
Snedeker, Jeffrey. "Review: Treatise-Method and Exercises \& 21 Etudes (Francis Orval)." The Horn Call 38, no. 1 (October, 2007): 83-84.

Thelander, Kristin. "Selected Etudes and Exercises for Specialized Practice." The Horn Call 24, no. 3 (May 1994): 53-59.

Thoman, Jessica. "Method and Etude Books and the Orchestra: How Method and Etude Books for Horn Reflect the Changing Orchestral Repertoire.” D.M.A. diss., Indiana University, 2006.

Thompson, Timothy F. "Extended Techniques for the Horn: An Historical Overview with Practical Performance Applications.” D.M.A. diss., University of Wisconsin-Madison, 1997.

Thompson, Virginia. "Review: 15 Études á notation classique et contemporaine (15 Etudes with classical and contemporary notation) (Éric Hulin).” The Horn Call 29, no. 3 (May 1999): 71. 


\section{Appendix A: Bibliographical Listing of Composers and Works}

Allen, Eric. Success in All Keys for Horn. Batavia, IL: Better Bands and Orchestras, 2009.

Allen, Eric. Low Range Studies for Horn. Batavia, IL: Better Bands and Orchestras, 2009.

Atwell, Bruce. Natural Horn/Valve Horn Technical Etudes: Strengthening Valve Horn Playing through Natural Horn Study. Tallahassee, FL: R.M. Williams Publishing, 2001.

Barrows, John. Development Exercises and Etudes for Horn. Atlanta, GA: Wind Music Publications, 2008.

Basler, Paul. Etudes for Horn. Tallahassee, FL: R.M. Williams Publishing, 1998.

Braun, Yehezkel. 12 Preludes for Unaccompanied Horn. Holon, Israel: Israel Brass Woodwind Publications, 1987.

Brown, Richard E. 18 Contemporary Etudes for Horn. Tallahassee, FL: RM Williams Publishing, 2005.

Burdick, Richard. Accuracy Studies for the French Hornist. Regina, SK, Canada: I Ching Music, 2008.

Colson, John F. and David J. Colson. Rhythm \& Pulse: Reading Music for the Trumpet and French Horn Player. Minneapolis, MN: McCoy’s Horn Library, 2001.

Concone, Giuseppe. 32 Lyrical Studies for Horn. Edited by Corbin Wagner. Detroit, MI: Cornopub, 2011.

Concone, Giuseppe. Studies for Horn. Edited by Robert Ashworth. Ampleforth, North Yorkshire, England: Emerson Edition, 1997.

Concone, Giuseppe, Mathilde Marchesi, and Heinrich Panofka. Studies in Lyricism for Horn in F. Edited by Larry Clark. New York: Carl Fischer, 2007.

Cottrell, David. Studies in Ancient Irish Song. Salem, CT: Cimarron Music Press, 2006.

Damm, Peter. Studien für Horn. Halberstadt, Germany: Musikverlag Bruno Uetz, 2006.

Davies, Alison. Four Studies: for Solo Horn. London: Broadbent \& Dunn, 1994. 
Dean, David. “Improving Left-Hand Finger Dexterity: Etudes for French Horn.” D.M.A. diss., University of Northern Colorado, 1993.

Deats, Carol. "Toward a pedagogy of extended techniques for horn derived from Vincent Persichetti's 'Parable for Solo Horn,' Opus 120.” D.M.A. diss., Texas Tech University, 2001.

Denniss, Graeme Wright. Studies for Low Horn. Melbourne, Australia: Dcomposition, 1993.

Dijoux, Marc. 50 Études Romantiques pour Cor D'Harmonie, Trompette, ou Clarinette. Macon, France: Editions Robert Martin, 1985.

Domnich, Heinrich. Selected Etudes for Two Horns from Methode de Premier et Second Cor. Edited and Arranged by Gregory Danner. Owensboro, KY: Medici Music Press, 1990.

Edwards, Brad. Simply Singing for Winds: A Wellspring of Melodies for Building Tone and Technique. Columbia, South Carolina: Brad Edwards, 2009.

Freiberg, Ritter von Gottfried. Naturhornschule: 160 Übungen für Naturhorn oderJagdhorn/160 Exercises for Natural Horn or Hunting Horn. Kirchheim, Germany: Hans Pizka Edition, 1985.

Freidman, Stanley. Four Etudes for Trumpet, Horn or Clarinet. Vuarmarens, Switzerland: Éditions Bim, 1996.

Grabois, Daniel. Twenty Difficult Etudes for the Horn's Middle Register. Daniel Grabois, 2009.

Hackleman, Martin, ed. 21 Characteristic Etudes for High Horn Playing. Bulle, CH: Éditions Bim, 1985.

Hansen, Jeremy Christian. "A Creative Pedagogical Approach to Hindemith's Music for Horn and Piano with Thirty Progressive Etudes.” D.M.A. thesis, University of Iowa, 2009.

Holcombe, Bill. 12 Intermediate Jazz Etudes for French Horn. West Trenton, NJ: Musicians Publications, 1994.

Hopper, Kathleen Kenyon. "A Performance Edition of Thirty Instructive and Melodic Exercises for French Horn by Vincenz Ranieri." D.M.A. diss., University of North CarolinaGreensboro, 2007. 
Hulin, Éric. 15 Études á notation classique et contemporaine (15 Etudes with classical and contemporary notation). Paris: Gérard Billaudot Éditeur, 1998.

Hulin, Éric. 20 Études Concertantes sur 5 Notes. Paris: Gérard Billaudot Éditeur, 1998.

Irwin, James. 85 Melodic and Rhythmic Studies. Dallas, TX: James Irwin, 1990.

Kling, Henri. 25 Studies and Preludes for Horn. Edited by Lee Bracegirdle. New York: International Music Co., 1985.

Koetsier, Jan. 13 Études Charactéristiques, op. 117. Crans-Montana, Switzerland: Editions Marc Reift, 2000.

Kopprasch, Georg. 60 Études, op. 5: pour Cor. Edited by Benny Sluchin. Paris: Éditions Musicales Européennes, 2000.

Kopprasch, Georg. Kopprasch Down Under: 46 Studies for Low Horn. Edited by Corbin Wagner. Detroit, MI: Cornopub, 2008.

Lewy, J.R. 12 Etudes por le Cor chromatique et le Cor simple avec accompagnement de Piano. EOD eBooks, 2011.

Lewy, J.R. 12 Etudes por le Cor chromatique et le Cor simple avec accompagnement de Piano. Edited by Michel Garcin-Marrou. Paris: Gérard Billaudot Éditeur, 2008.

Lewy, J.R. 12 Etudes por le Cor chromatique et le Cor simple avec accompagnement de Piano. Edited by Thomas Z. Hale. Austin, TX: Thomas Z. Hale, 2002.

Lewy, J.R. 12 Etudes por le Cor chromatique et le Cor simple avec accompagnement de Piano. Edited by William N. O'Bannion. Carrollton, TX: O'Bannion Music, 2002.

Lipsius, Fred. Reading Key Jazz Rhythms. Edited by John Clark. Burlington, VT: Advance Music, 1997.

Manous, Carlyle. 53 Studies in Rhythm in Treble Clef. Tallahassee, FL: R.M. Williams Publishing, 1999.

Marchesi, Mathilde. 24 Volkalisen für Horn. Edited by William S. Fatch. Hofheim-Leipzig, Germany: Friedrich Hofmeister Musikverlag, 1997. 
Martin, Jean-Louis. 20 Etudes pour cor en fa. Paris: Gérard Billaudot Éditeur, 2000.

Matosinhos, Ricardo. 12 Jazzy Etudes for Horn. Enschede, Netherlands: Phoenix Music, 2010.

Merck, J. H. 24 Études pour Cor. Kirchheim, Germany: Hans Pizka Edition, 1985.

McCoy, Marvin M. 46 Progressive Exercises for Low Horn. Minneapolis, MN: McCoy’s Horn Library, 1986.

Miles, Patrick. Low Horn Etudes and Drills for the Intermediate Horn Player. Eau Claire, WI: Really Good Music, 2009.

Miller, Brett. Fourteen Concert Etudes on the Themes of Richard Strauss. Silver Spring, MD: Horn Dog Publishing, 2007.

Miller, Brett. Fifteen Concert Etudes on the Themes of Johannes Brahms. Silver Spring, MD: Horn Dog Publishing, 2007.

Miller, Brett. Sixteen Concert Etudes on the Themes of Gustav Mahler. Silver Spring, MD: Horn Dog Publishing, 2007.

Muth, Fritz. 10 Uebungen zur Bildung d. Gelaeufigkeit op.51a. Kirchheim, Germany: Hans Pizka Edition, 1985.

Oliveros, Pauline. The Oliveros Interval Studies. Edited by Richard Burdick. Woodland, CA: IChing Music, 2002.

Orval, Francis. Treatise-Method and Exercises \& 21 Etudes. Crans-Montana, Switzerland: Editions Marc Reift, 2007.

Proust, Pascal. 15 Pièces en forme d'études. Paris: Éditions Combre, 1996.

Proust, Pascal. 25 Études sur des soli d'orchestre (avec transpositions). Paris: Éditions Combre, 2002.

Proust, Pascal. 40 Études de style pour cor. Paris: Éditions Combre, 2004.

Randall, Ronald F. Twenty Etudes for the Advanced Student. Burdick's Editions, 2000. 
Runge, Jürgen. Studies for Horn and Piano. Leipzig, Germany: Friedrich Hofmeister Musikverlag, 2007.

Schantl, Josef. 92 Beginning Exercises for Valved Horn. Kirchheim, Germany: Hans Pizka Edition, 1985.

Schantl, Josef. Etudes for the Natural Horn. Edited by Henri Kling and Milan Yancich. Atlanta, GA: Wind Music Publications, 2005.

Shaw, Lowell E. Just Desserts: Frippery Style for Horn. Buffalo, NY: The Hornist's Nest, 1999.

Suttner, Josef. Praktische Studien für Horn: based on the introduction to the stage works of Richard Wagner. Edited by Peter Damm. Halberstadt, Germany: Musikverlag Bruno Uetz, 2006.

Thompson, Timothy F. "Extended Techniques for the Horn: An Historical Overview with Practical Performance Applications.” D.M.A. diss., University of Wisconsin-Madison, 1997.

Uber, David. Early Rhythmic Studies for Horn. North Vancouver, British Columbia: Touch of Brass Music Co., 1985.

Uber, David. Solo Etudes for Horn in F. Buffalo, NY: The Hornist's Nest, 2001.

Zarzo, Vicente. 10 Estudios para Trompa: Sobre una idea de Bernard Krol, op. 7. Valencia, España: Editorial de Música S. A., 1995.

Zarzo, Vicente. 12 Estudios para Trompa Natural, op. 6. Valencia, España: Editorial de Música S. A., 1995. 


\section{Appendix B: Alphabetical Listing of Publishers}

3-C Musikverlag \& Notengrafix

Advance Music

Better Bands and Orchestras

Broadbent \& Dunn

Carl Fischer

Cornopub

Dcomposition

Éditions Bim

Éditions Combre

Editions Marc Reift

Éditions Musicales Européennes

Editions Robert Martin

Editorial de Música S. A.

Emerson Edition

Friedrich Hofmeister Musikverlag

Gérard Billaudot Éditeur

Hans Pizka Editions

Horn Dog Publishing

I Ching Music

International Music Co.

Israel Brass Woodwind Publications

McCoy's Horn Library

Medici Music Press

Mountain Peak Music

Musicians Publications

Musikverlag Bruno Uetz

Phoenix Music

R.M. Williams Publishing

Really Good Music

The Hornist's Nest

Touch of Brass Music Co.

Wind Music Publications 


\section{Appendix C: Chronological Listing of Compositions by Publication Date}

10 Uebungen zur Bildung d. Gelaeufigkeit op. 51a. Muth, Fritz. 1985.

21 Characteristic Etudes for High Horn Playing. Hackleman, Martin, ed. 1985.

24 Études pour Cor. Merck, J. H. 1985.

25 Studies and Preludes for Horn. Kling, Henri. Edited by Lee Bracegirdle. 1985.

50 Études Romantiques pour Cor D'Harmonie, Trompette, ou Clarinette. Dijoux, Marc. 1985.

92 Beginning Exercises for Valved Horn. Schantl, Josef. 1985.

Early Rhythmic Studies for Horn. Uber, David. 1985.

Naturhornschule: 160 Übungen für Naturhorn oderJagdhorn/160 Exercises for Natural Horn or Hunting Horn. Freiberg, Ritter von Gottfried. 1985.

46 Progressive Exercises for Low Horn. McCoy, Marvin M. 1986.

12 Preludes for Unaccompanied Horn. Braun, Yehezkel. 1987.

85 Melodic and Rhythmic Studies. Irwin, James. 1990.

Selected Etudes for Two Horns from Methode de Premier et Second Cor. Domnich, Heinrich. 1990.

"Improving Left-Hand Finger Dexterity: Etudes for French Horn.” Dean, David. 1993.

Studies for Low Horn. Denniss, Graeme Wright. 1993.

12 Intermediate Jazz Etudes for French Horn. Holcombe, Bill. 1994.

Four Studies: for Solo Horn. Davies, Alison. 1994.

10 Estudios para Trompa, op. 7. Zarzo, Vicente. 1995.

12 Estudios, op. 6. Zarzo, Vicente. 1995.

15 Pièces en forme d'études. Proust, Pascal. 1996.

Four Etudes for Trumpet, Horn or Clarinet. Freidman, Stanley. 1996.

24 Volkalisen für Horn. Marchesi, Mathilde. Edited by William S. Fatch. 1997.

"Extended Techniques for the Horn: An Historical Overview with Practical Performance

Applications." Thompson, Timothy F. 1997.

Reading Key Jazz Rhythms. Lipsius, Fred. 1997.

Studies for Horn. Concone, Giuseppe. Edited by Robert Ashworth. 1997.

15 Études á notation classique et contemporaine (15 Etudes with classical and contemporary notation). Hulin, Éric. 1998.

20 Études Concertantes sur 5 Notes. Hulin, Éric. 1998.

Etudes for Horn, Vols. 1 \& 2. Basler, Paul. 1998.

53 Studies in Rhythm in Treble Clef. Manous, Carlyle. 1999.

Just Desserts: Frippery Style for Horn. Shaw, Lowell E. 1999.

13 Études Charactéristiques, op. 117. Koetsier, Jan. 2000.

20 Etudes pour cor en fa. Martin, Jean-Louis. 2000.

60 Études, op. 5: pour Cor. Kopprasch, Georg. 2000.

Twenty Etudes for the Advanced Student. Randall, Ronald F. 2000.

Solo Etudes for Horn in F. Uber, David. 2001. 
Natural Horn/Valve Horn Technical Etudes: Strengthening Valve Horn Playing through Natural Horn Study. Atwell, Bruce. 2001.

Rhythm \& Pulse: Reading Music for the Trumpet and French Horn Player. Colson, John F. and David J. Colson. 2001.

"Toward a pedagogy of extended techniques for horn derived from Vincent Persichetti's "Parable for Solo Horn", Opus 120.” Deats, Carol. 2001.

12 Etudes por le Cor chromatique et le Cor simple avec accompagnement de Piano. Lewy, J.R. Edited by Thomas Z. Hale. 2002.

12 Etudes por le Cor chromatique et le Cor simple avec accompagnement de Piano. Lewy, J.R. Edited by William N. O'Bannion. 2002.

25 Études sur des soli d'orchestre (avec transpositions). Proust, Pascal. 2002.

The Oliveros Interval Studies. Oliveros, Pauline. 2002.

40 Études de style pour cor. Proust, Pascal. 2004.

18 Contemporary Etudes for Horn. Brown, Richard E. 2005.

Etudes for the Natural Horn. Schantl, Josef. 2005.

Praktische Studien für Horn: based on the introduction to the stage works of Richard Wagner.

Suttner, Josef. 2006.

Studien für Horn. Damm, Peter. 2006.

Studies in Ancient Irish Song. Cottrell, David. 2006.

"A Performance Edition of Thirty Instructive and Melodic Exercises for French Horn by Vincenz Ranieri.” Hopper, Kathleen Kenyon. 2007.

Fourteen Concert Etudes on the Themes of Richard Strauss. Miller, Brett. 2007.

Fifteen Concert Etudes on the Themes of Johannes Brahms. Miller, Brett. 2007.

Sixteen Concert Etudes on the Themes of Gustav Mahler. Miller, Brett. 2007.

Studies for Horn and Piano. Runge, Jürgen. 2007.

Studies in Lyricism for Horn in F. Concone, Giuseppe, Mathilde Marchesi, and Heinrich

Panofka. Edited by Larry Clark. 2007.

Treatise-Method and Exercises \& 21 Etudes. Orval, Francis. 2007.

12 Etudes por le Cor chromatique et le Cor simple avec accompagnement de Piano. Lewy, J.R.

Edited by Michel Garcin-Marrou. 2008.

Accuracy Studies for the French Hornist. Burdick, Richard. 2008.

Development Exercises and Etudes for Horn. Barrows, John. 2008.

Kopprasch Down Under: 46 Studies for Low Horn. Kopprasch, Georg. Edited by Corbin Wagner. 2008.

"A Creative Pedagogical Approach to Hindemith's Music for Horn and Piano with Thirty Progressive Etudes." Hansen, Jeremy Christian. 2009.

Low Horn Etudes and Drills for the Intermediate Horn Player. Miles, Patrick. 2009.

Low Range Studies for Horn. Allen, Eric. 2009.

Simply Singing for Winds: A Wellspring of Melodies for Building Tone and Technique. Edwards, Brad. 2009. 
Success in All Keys for Horn. Allen, Eric. 2009.

Twenty Difficult Etudes for the Horn's Middle Register. Grabois, Daniel. 2009.

12 Jazzy Etudes for Horn. Matosinhos, Ricardo. 2010.

12 Etudes por le Cor chromatique et le Cor simple avec accompagnement de Piano. Lewy, J.R. 2011

32 Lyrical Studies for Horn. Concone, Giuseppe. Edited by Corbin Wagner. 2011. 


\section{Appendix D: Contemporary Etude Books Listed Alphabetically by Composer (Newly Composed or Published Works that are not Editions of Previously Published Works)}

Allen, Eric. Success in All Keys for Horn.

Allen, Eric. Low Range Studies for Horn.

Atwell, Bruce. Natural Horn/Valve Horn Technical Etudes: Strengthening Valve Horn Playing through Natural Horn Study.

Barrows, John. Development Exercises and Etudes for Horn. ${ }^{27}$

Basler, Paul. Etudes for Horn.

Braun, Yehezkel. 12 Preludes for Unaccompanied Horn.

Brown, Richard E. 18 Contemporary Etudes for Horn.

Burdick, Richard. Accuracy Studies for the French Hornist.

Colson, John F. and David J. Colson. Rhythm \& Pulse: Reading Music for the Trumpet and French Horn Player.

Damm, Peter. Studien für Horn.

Davies, Alison. Four Studies: for Solo Horn.

Dean, David. "Improving Left-Hand Finger Dexterity: Etudes for French Horn."

Deats, Carol. "Toward a pedagogy of extended techniques for horn derived from Vincent Persichetti's "Parable for Solo Horn", Opus 120."

Denniss, Graeme Wright. Studies for Low Horn.

Edwards, Brad. Simply Singing for Winds: A Wellspring of Melodies for Building Tone and Technique.

Freiberg, Ritter von Gottfried. Naturhornschule: 160 Übungen für Naturhorn oderJagdhorn/160 Exercises for Natural Horn or Hunting Horn. ${ }^{28}$

Freidman, Stanley. Four Etudes for Trumpet, Horn or Clarinet.

Grabois, Daniel. Twenty Difficult Etudes for the Horn's Middle Register.

Hansen, Jeremy Christian. "A Creative Pedagogical Approach to Hindemith's Music for Horn and Piano with Thirty Progressive Etudes."

Holcombe, Bill. 12 Intermediate Jazz Etudes for French Horn.

Hulin, Éric. 15 Études á notation classique et contemporaine (15 Etudes with classical and contemporary notation).

Hulin, Éric. 20 Études Concertantes sur 5 Notes.

Irwin, James. 85 Melodic and Rhythmic Studies.

Koetsier, Jan. 13 Études Charactéristiques, op. 117.

Lipsius, Fred. Reading Key Jazz Rhythms.

Martin, Jean-Louis. 20 Etudes pour cor en fa.

Matosinhos, Ricardo. 12 Jazzy Etudes for Horn.

27 This is a reproduction of the original material that was never published until recently in 2008.

28 Freiberg died in 1962, but the earliest publication date for this work is 1985. 
Merck, J. H. 24 Études pour Cor.

McCoy, Marvin M. 46 Progressive Exercises for Low Horn.

Miles, Patrick. Low Horn Etudes and Drills for the Intermediate Horn Player.

Miller, Brett. 2007. Fourteen Concert Etudes on the Themes of Richard Strauss.

Miller, Brett. 2007. Fifteen Concert Etudes on the Themes of Johannes Brahms.

Miller, Brett. 2007. Sixteen Concert Etudes on the Themes of Gustav Mahler.

Muth, Fritz. 10 Uebungen zur Bildung d. Gelaeufigkeit op.51a.

Oliveros, Pauline. The Oliveros Interval Studies. ${ }^{29}$

Orval, Francis. Treatise-Method and Exercises \& 21 Etudes.

Proust, Pascal. 15 Pièces en forme d'études.

Proust, Pascal. 25 Études sur des soli d'orchestre (avec transpositions).

Proust, Pascal. 40 Études de style pour cor.

Randall, Ronald F. Twenty Etudes for the Advanced Student.

Runge, Jürgen. Studies for Horn and Piano.

Schantl, Josef. 92 Beginning Exercises for Valved Horn. ${ }^{30}$

Suttner, Josef. Praktische Studien für Horn: based on the introduction to the stage works of Richard Wagner.

Thompson, Timothy F. "Extended Techniques for the Horn: An Historical Overview with Practical Performance Applications."

Uber, David. Early Rhythmic Studies for Horn.

Uber, David. Solo Etudes for Horn in F.

Zarzo, Vicente. 12 Estudios para Trompa Natural, op. 6.

Zarzo, Vicente. 10 Estudios para Trompa: Sobre una idea de Bernard Krol, op. 7.

29 These studies were written in 1959, but were not published until 2002.

30 Schantl died in 1902, but the earliest publication date for this work is 1985. 